\title{
Gram-scale asymmetric synthesis of fluorinated amino acids using a chiral nickel(II) complex
}

Thomas Hohmann ${ }^{1}$, Michael Dyrks ${ }^{1}$, Suvrat Chowdhary ${ }^{1}$, Manuela Weber ${ }^{2}$, Duy Nguyen ${ }^{1}$, Johann Moschner ${ }^{1}$ and Beate Koksch ${ }^{1}$

Institute of Chemistry and Biochemistry, Freie Universität Berlin

${ }^{1}$ Arnimallee 20, 14195 Berlin, Germany

${ }^{2}$ Fabeckstraße 34/36, 14195 Berlin, Germany

\section{Corresponding author:}

Beate Koksch - Institute of Chemistry and Biochemistry, Freie Universität Berlin ${ }^{1}$ Arnimallee 20, 14195 Berlin, Germany

Email: beate.koksch@fu-berlin.de

\begin{abstract}
Fluorinated amino acids play an important role in the field of peptide and protein engineering. Although several different syntheses have been published in recent decades, obtaining fluorinated amino acids on a gram-scale still poses a challenge. Furthermore, the described pathways to obtain fluorinated amino acids are based on different synthetic strategies, making a uniform approach from similar starting materials highly interesting. Chiral $\mathrm{Ni}$ (II) complexes were introduced as powerful tools in the synthesis of non-canonical amino acids. In this work, we present a strategy for the synthesis of a diverse range of fluorinated amino acids from the corresponding $\mathrm{Ni}$ (II) complex on a gram-scale from which the products can be obtained in enantiopure form ( $>94 \%$ ee). In addition, we describe syntheses for alkyl iodide building blocks which are required for the alkylation reactions with the corresponding Ni(II) complex. Finally, we characterized the synthesized fluorinated amino acids with regard to their hydrophobicity and $\alpha$-helix propensity.
\end{abstract}

\section{Introduction}

The element fluorine is a powerful tool in peptide and protein engineering and can be used to alter a broad range of properties such as thermal stability, metabolic stability, and proteolytic resistance. ${ }^{1,2}$ Furthermore, fluorine can be used to direct and modify peptide self-assembly 
processes leading to the formation of fluorinated supramolecular structures. ${ }^{3}$ In general, fluorine can be introduced into peptides and proteins using fluorinated amino acids as building blocks in solution or solid-phase peptide synthesis (SPPS). ${ }^{4,5}$ For the syntheses of fluorinated variants of natural and non-natural amino acids, a large number of synthetic methods has been published such as the application of either commercially available fluorinated synthons or electrophilic or nucleophilic fluorinating reagents. Recently, our group has published a review about the diverse approaches for the synthesis of different classes of fluorinated amino acids. ${ }^{6}$ One powerful synthetic strategy is the application of chiral nickel complexes. First introduced by Belokon et al. ${ }^{7}$, a variety of chiral nickel complexes were established for the asymmetric synthesis of non-canonical amino acids or for the dynamic kinetic resolution (DKR) of racemic amino acid mixtures in the last twenty years. ${ }^{8}$ Different reaction types such as alkylations with primary or secondary alkyl halides, Mannich reactions, and Michael additions can be used in this context. ${ }^{8}$ The described Ni(II) complexes are constructed from a tridentate proline-derived Schiff base ligand and a canonical amino acid such as glycine or alanine. One crucial achievement was reported by the group of V. Soloshonok describing a trichlorinated version of the $\mathrm{Ni}(\mathrm{II})$ complex 1 which shows excellent stereoselectivities in reactions with alkyl halides. ${ }^{9}$ Furthermore, the ligand can be recovered making this process atom-economical. Recently, a large-scale synthesis of the Soloshonok Ni(II) complex 1 was reported giving access to this important building block on a gram scale. ${ }^{10-12}$

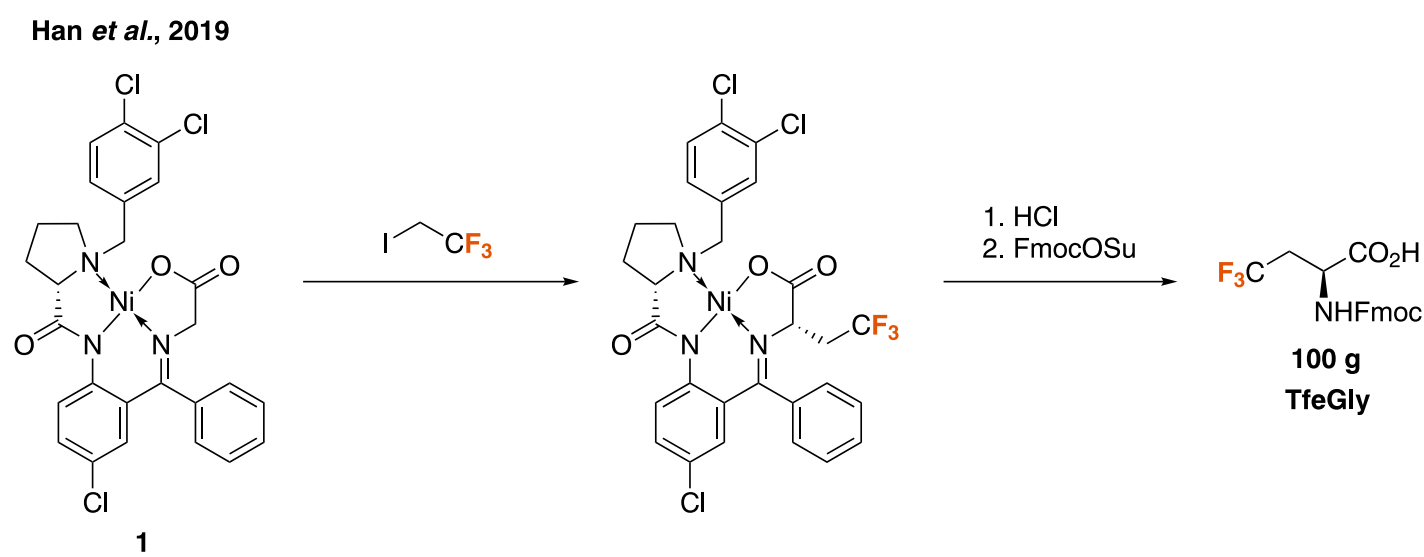

Scheme 1: Synthesis of TfeGly using the chiral Ni(II) complex 1.

The described Ni(II) complex 1 was recently used in the asymmetric gram-scale preparation of trifluoroethylglycine (TfeGly) (Scheme 1). ${ }^{13}$ These results indicated the great potential of the $\mathrm{Ni}(\mathrm{II})$ complex 1 in the synthesis of fluorinated amino acids. ${ }^{13,14}$ In this work, we report on the 
development of a general procedure that enables access to a broad range of differently fluorinated amino acids based on the Ni(II) complex 1.

Table 1: Entries 1-6: Fluorinated amino acids in the focus of this work and corresponding previous synthesis parameters. Entry 7: New strategy using the chiral Ni(II)-complex.

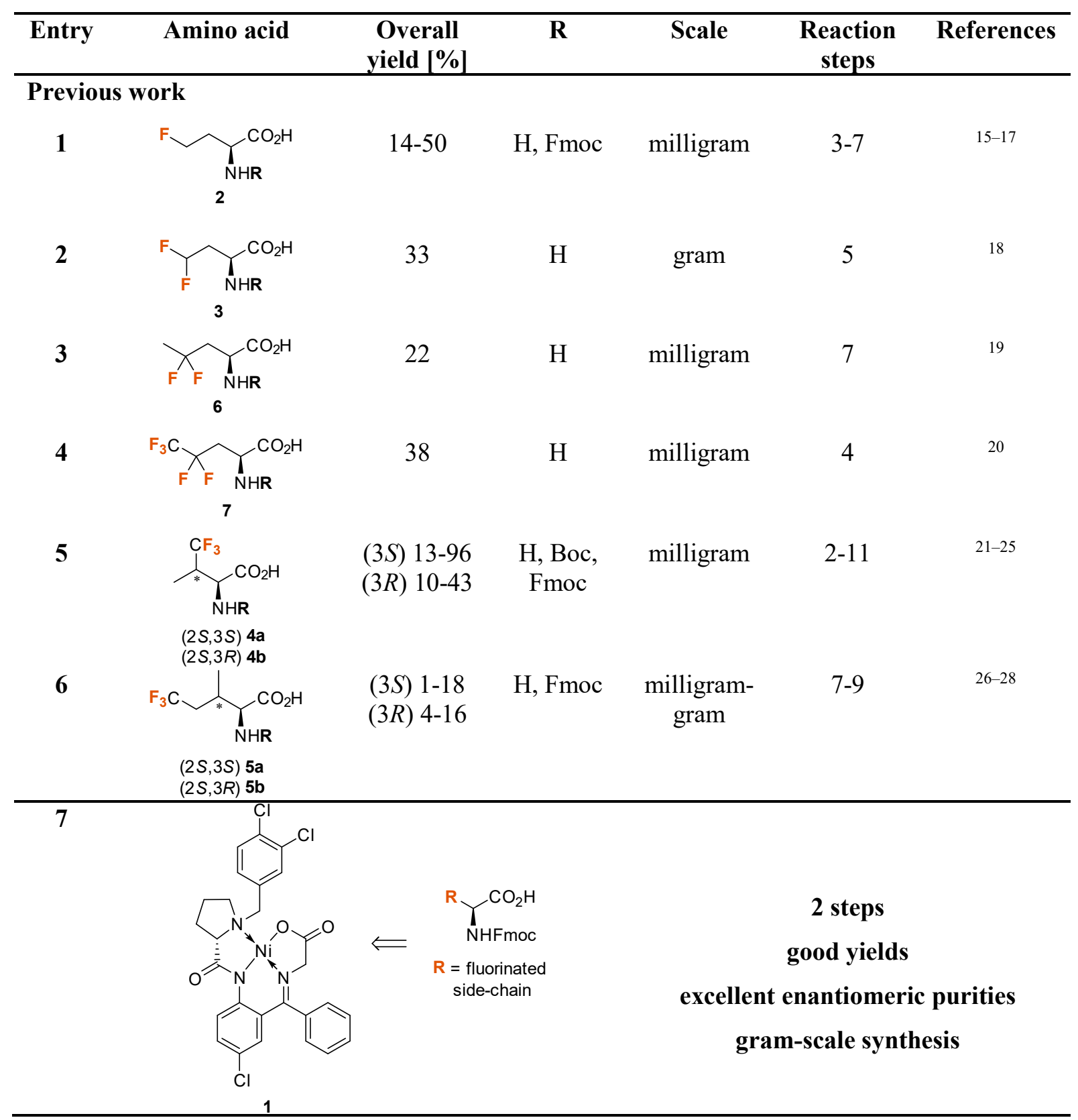

We focused our work on the synthesis of three different classes of fluorinated amino acids (Table 1):

(1) the mono- and difluorinated variants of 2-aminobutyric acid; monofluoroethylglycine 2 [MfeGly], and difluoroethylglycine 3 [DfeGly] (Table 1, entry 1-2), 
(2) the $\beta$-branched amino acids $2 S, 3 S$-trifluorovaline 4a $[(2 S, 3 S)$-TfVal $], \quad(2 S$, $3 R)$-trifluorovaline $4 \mathbf{b}\left[(2 S, 3 R)\right.$-TfVal] (Table 1, entry 5), $5^{3}$-(2S, 3S)-trifluorisoleucine 5a [ $5^{3}-(2 S, 3 S)$-Tflle], and $5^{3}-(2 S, 3 R)$-trifluoroisoleucine $\mathbf{5 b}\left[5^{3}-(2 S, 3 R)\right.$-Tflle] (Table 1, entry 6),

(3) the difluorinated and pentafluorinated variants of 2-aminopentanoic acid difluoropropylglycine 6 [DfpGly], and pentafluoropropylglycine 7 [PfpGly], (Table 1, entry 3-4).

Different synthetic methods were published in the last years to obtain the described compounds. ${ }^{15-28}$ However, the described approaches are multi-step syntheses that require several chromatographic purification steps and follow different synthetic strategies. In addition, most of these amino acids could only be isolated on a milligram-scale. Usually, the synthesis of either $N$-unprotected or $N$-Boc-protected amino acids was described (Table 1, Entry 2-5). Herein, we present a uniform 2-step pathway from the Ni(II) complex 1 to obtain the desired fluorinated amino acids on a gram-scale in their Fmoc-protected form and, thus, prepared for their application in solid-phase peptide synthesis. Additionally, we describe the synthesis of several alkyl iodide building blocks that are employed in the alkylation step. Lastly, the synthesized fluorinated amino acids were characterized with respect to their hydrophobicity and $\alpha$-helix propensity.

\section{Results and Discussion}

Synthesis of alkyl iodide building blocks Alkyl iodides required for the syntheses of TfVal 4 and DfpGly 6 are not commercially available or are rather expensive. Our first goal was the establishment of a gram-scale synthesis of the corresponding alkyl iodides. The fluorinated alcohols $\mathbf{8}$ and $\mathbf{1 1}$ were used as starting materials since they are readily available and can easily be transformed into the desired compounds. We started our studies using 2-difluoropropan-1-ol 8. First, several conditions such as Appel reaction, tosylation or mesylation with subsequent nucleophilic iodination, were employed without satisfying results since small highly fluorinated molecules are known to cause problems in nucleophilic substitution reactions. ${ }^{29,30}$ This challenge was overcome by the introduction of a nonaflate leaving group. Hanack and Ullmann described the synthesis of 1-trifluoro-2-iodopropane $\mathbf{1 0}$ using the corresponding nonaflate as a powerful leaving group during the iodination step (Scheme 2, a). ${ }^{30}$ 


\section{a.}

Hanack and UlImann, 1989

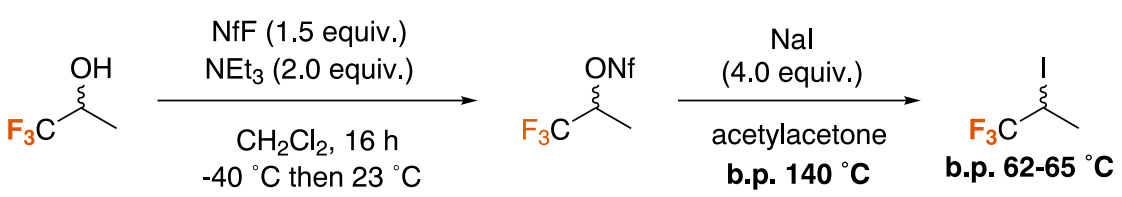

b. [decagram-scale]

NfF (1.5 equiv.)

$\mathrm{R}_{2}^{\mathrm{R}_{1}} \mathrm{OH}$
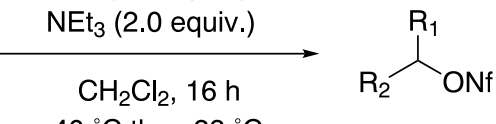

[decagram-scale]

$-40{ }^{\circ} \mathrm{C}$ then $23^{\circ} \mathrm{C}$

$\mathrm{R}_{1}=\mathrm{H} \quad \mathrm{R}_{2}=\mathrm{CF}_{2} \mathrm{CH}_{3} \quad 8$

$\mathrm{R}_{1}=\mathrm{Me} \quad \mathrm{R}_{2}=\mathrm{CF}_{3} \quad 11$

$953 \%$

$1262 \%$

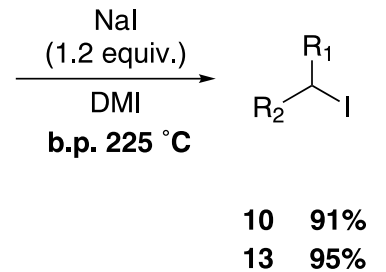

Scheme 2: a. Previously reported synthesis of 1-trifluoro-2-iodopropane 10. b. Gram-scale synthesis of fluorinated alkyl iodide compounds from the corresponding fluorinated alcohols.

We applied the conditions reported by Hanack and Ullmann and could obtain both alkyl nonaflates 9 and $\mathbf{1 2}$ in good yields. To facilitate the purification of the alkyl iodide products $\mathbf{1 0}$ and 13 by distillation, the final step was modified. Several high-boiling solvents were screened showing that 1,3-dimethyl-2-imidazolidinone (DMI) is the most promising candidate (Supporting Information, Table S1). Finally, the desired alkyl iodides $\mathbf{1 0}$ and $\mathbf{1 3}$ could be isolated on a decagram-scale and in excellent yields.

Synthesis of MfeGly and DfeGly Chiral Ni(II) complex 1 was synthesized according to the conditions published by Wang et al. ${ }^{9}$ The alkylation step was carried out on a decagram scale using the reported conditions ${ }^{14}$ (Figure 3). In addition, we looked more closely at the influence of the reaction temperature on the outcome of this conversion. Lower temperature $\left(0^{\circ} \mathrm{C}\right)$ resulted in slightly poorer yields but improved diastereoselectivity (96\%de, Supporting Information, Table S2). 


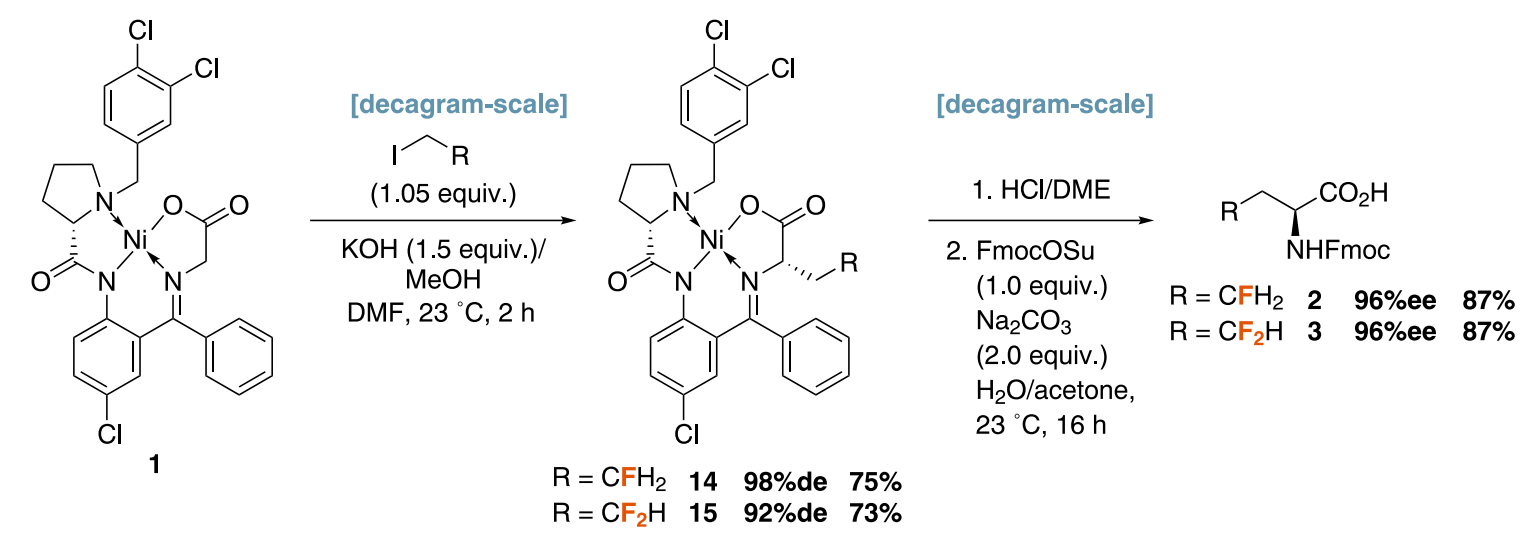

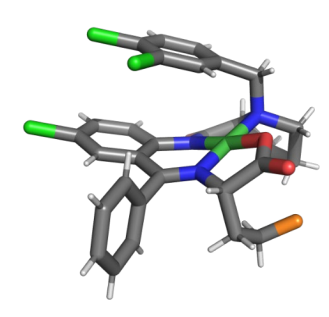

14

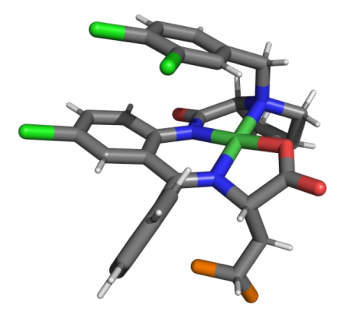

15

Scheme 3: Gram-scale synthesis of Fmoc-MfeGly 2 and Fmoc-DfeGly 3 using the chiral Ni(II) complex 1. Ni(II) Schiff base complexes of MfeGly 14 and DfeGly 15 were further characterized by X-ray crystallography.

Both alkylated $\mathrm{Ni}(\mathrm{II})$ complexes $\mathbf{1 4}$ and $\mathbf{1 5}$ were obtained in great yields with high diastereomeric purities (>92\%de) and $\mathrm{Ni}(\mathrm{II})$ complexes 14 and 15 were further characterized by X-ray crystallography. Subsequent one-pot hydrolysis of the complex and Fmoc-protection of the fluorinated amino acids led to the formation of the desired amino acids $\mathbf{2}$ and $\mathbf{3}$. Both Fmoc-protected amino acids were isolated on a gram scale with high enantiomeric purities (96\%еe).

Synthesis of $\beta$-branched fluorinated amino acids We started our efforts with the alkylation reaction of the $\mathrm{Ni}(\mathrm{II})$ complex with 1-trifluoro-3-iodobutane. Employing the conditions reported by Soloshonok et al. ${ }^{14}$ using $\mathrm{KOH} / \mathrm{MeOH}$ led to unsatisfactory yields (Table 1, Entry 3). 
Table 2: Screening conditions for the alkylation step using 1-trifluoro-3-iodobutane
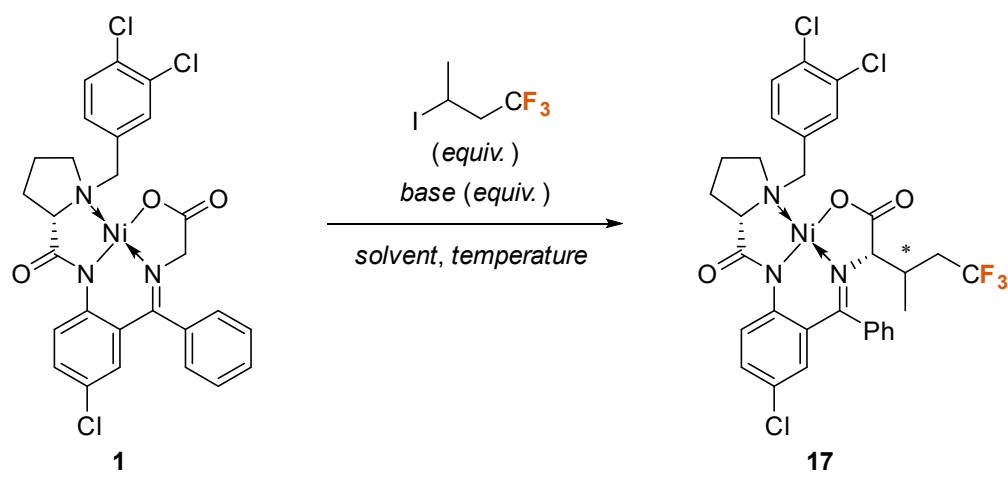

\begin{tabular}{|c|c|c|c|c|c|c|}
\hline Entry & Base & $\begin{array}{c}\text { Base } \\
\text { [equiv.] }\end{array}$ & $\begin{array}{c}\text { Side } \\
\text { Chain } \\
\text { [equiv.] }\end{array}$ & Solvent & $\begin{array}{c}\text { Temperature } \\
{\left[{ }^{\circ} \mathrm{C}\right]}\end{array}$ & $\begin{array}{l}\text { Yield } \\
{[\%]^{*}}\end{array}$ \\
\hline 1 & $\mathbf{N a H}$ & 1.2 & 1.05 & DMF & 23 & 22 \\
\hline 2 & KOtBu & 1.2 & 1.05 & DMF & 23 & 5 \\
\hline 3 & $\begin{array}{c}\text { КОН/ } \\
\text { МеOH }\end{array}$ & 1.05 & 1.05 & DMF & 23 & 2 \\
\hline 4 & $\mathrm{NaH}$ & 1.2 & 1.05 & THF & 23 & 11 \\
\hline 5 & $\mathrm{NaH}$ & 1.2 & 1.05 & MeCN & 23 & 4 \\
\hline 6 & $\mathrm{NaH}$ & 1.2 & 1.05 & DMF/ & 23 & 17 \\
\hline & & & & THF & & \\
\hline 7 & $\mathrm{NaH}$ & 1.2 & 1.5 & DMF & 0 & 15 \\
\hline 8 & $\mathrm{NaH}$ & 1.2 & 2.0 & $\mathrm{DMF}$ & 0 & 4 \\
\hline 9 & $\mathrm{NaH}$ & 1.2 & 1.05 & $\mathrm{DMF}$ & 0 & 26 \\
\hline 10 & $\mathrm{NaH}$ & 2.0 & 1.05 & DMF & 0 & 42 \\
\hline 11 & $\mathrm{NaH}$ & 3.0 & 1.05 & DMF & 0 & 47 \\
\hline 12 & $\mathrm{NaH}$ & 3.0 & 1.05 & DMF & 23 & 36 \\
\hline 13 & $\mathrm{NaH}$ & 3.0 & 1.05 & $\mathrm{DMF}$ & 0 & 47 \\
\hline 14 & $\mathrm{NaH}$ & 3.0 & 1.05 & DMF & -20 & 15 \\
\hline
\end{tabular}

${ }^{19} \mathrm{~F}$-NMR yield using 2-chloro-4-fluorotoluene as an internal standard. 
Therefore, we looked at different bases and screened a broad range of different reaction conditions including solvent and temperature (Table 2, for the complete screening summary, see Supporting Information, Table S3). The best results were obtained using sodium hydride at $0{ }^{\circ} \mathrm{C}$ (Table 2, Entry 11). Based on these optimized conditions, we were able to synthesize TfVal 4 and TfIle 5 in gram quantities (Scheme 4).

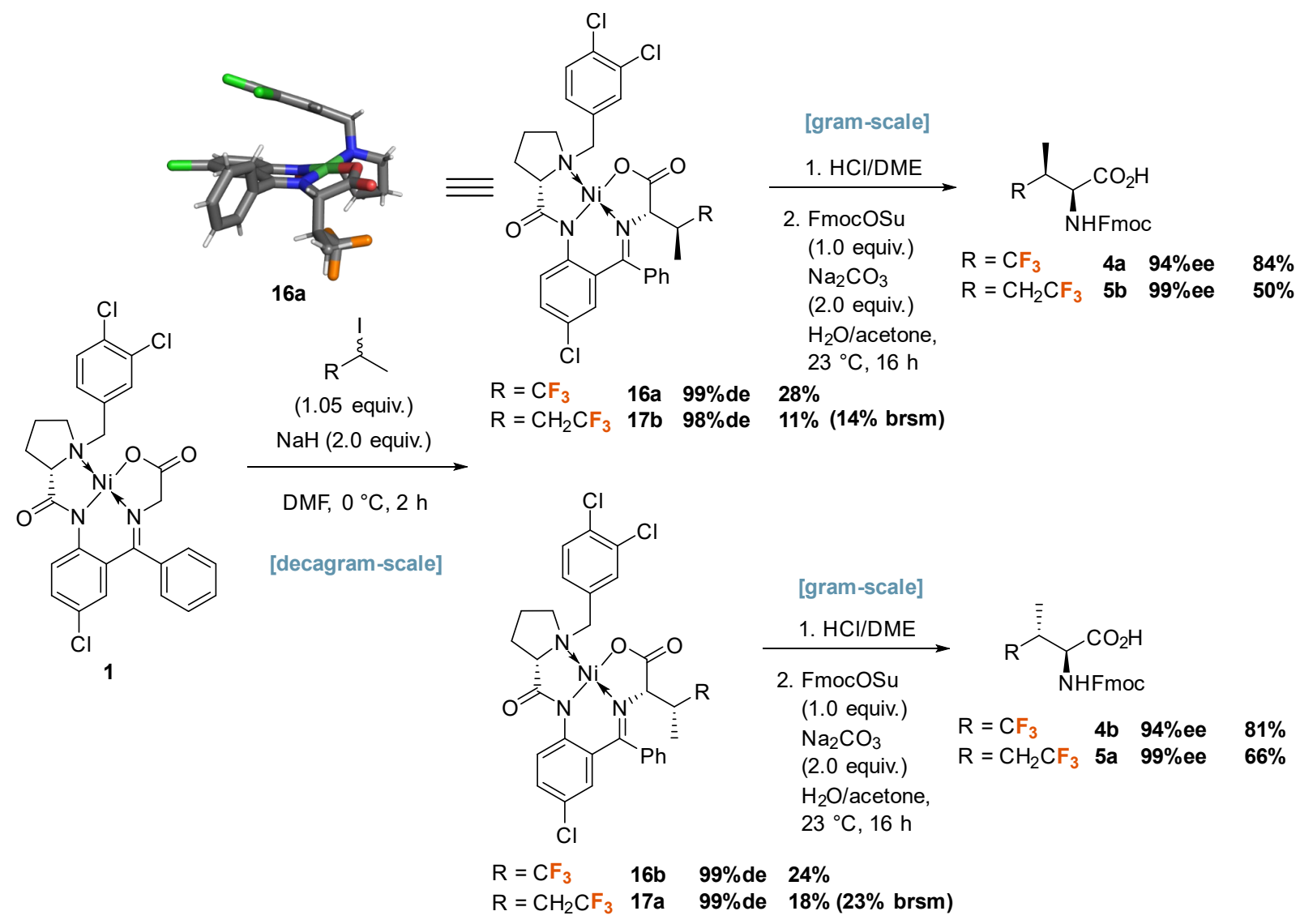

Scheme 4: Gram-scale synthesis of the TfVal 4 and TfIle 5 diastereomers using the chiral Ni(II) complex 1. Stereochemistry of the Ni(II) complex of $(2 S, 3 S)$-TfVal $\mathbf{1 6 a}$ was supported by X-ray crystallographic structure determination (for the sake of clarity, disordered atoms are not displayed).

The alkylated $\mathrm{Ni}$ (II) complexes $\mathbf{1 6}$ and $\mathbf{1 7}$ were obtained in moderate yields with high diastereomeric purities (>98\%de). The corresponding diastereomers could be separated by flash column chromatography. Stereochemistry of the alkylated Ni(II) complexes was determined by X-ray diffraction or by 1D NOESY experiments (Supporting Information). After hydrolysis and Fmoc-protection both diastereomers of TfVal 4 and Tffle 5 were isolated with excellent enantiomeric purities (>94\%ee).

Synthesis of fluorinated norvaline derivatives For the synthesis of difluorinated 6 and pentafluorinated 7 variants of norvaline, we looked at different reaction conditions which 
already showed good results in previous syntheses. Again, the use of $\mathrm{KOH} / \mathrm{MeOH}$ during the alkylation reaction provided the targeted compounds in poor yields (Supporting Information, Tables S5 and S6). As previously reported for the synthesis of $\beta$-branched amino acids, the best results were observed using sodium hydride. Different base equivalents were screened showing that in contrast to TfVal 4 and TfIle 5 (2.0 equiv.) now only 1.3 equivalents were sufficient for both amino acids 6 and 7.

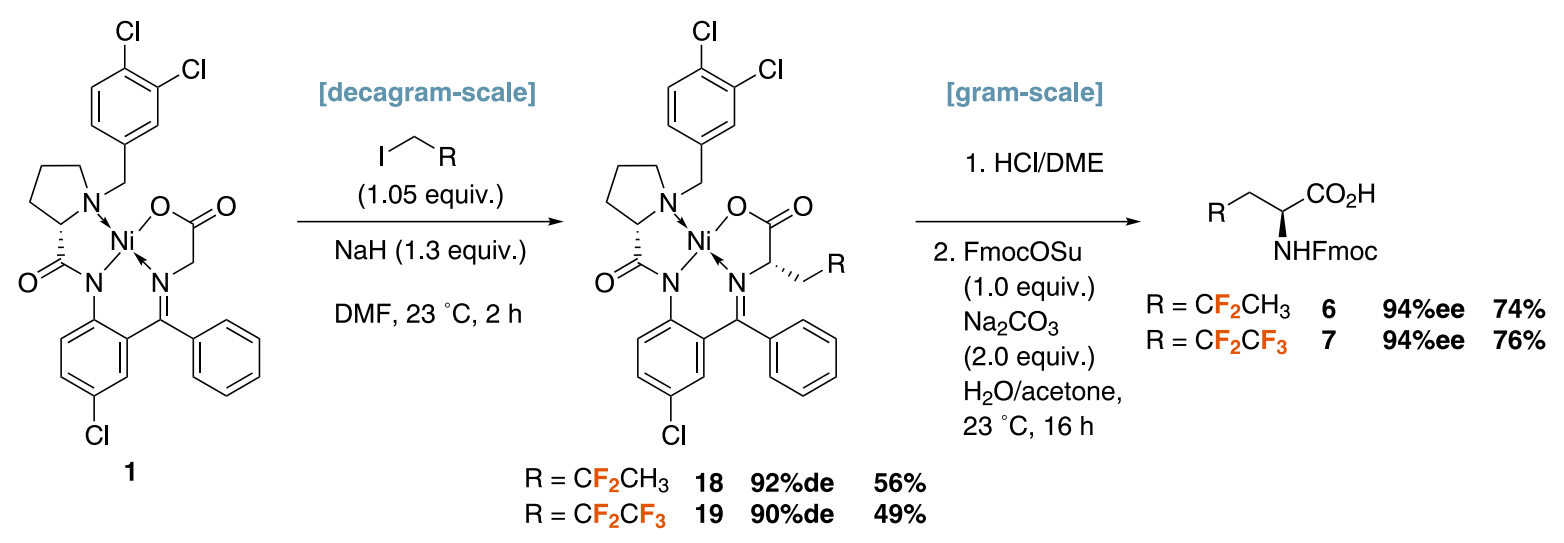

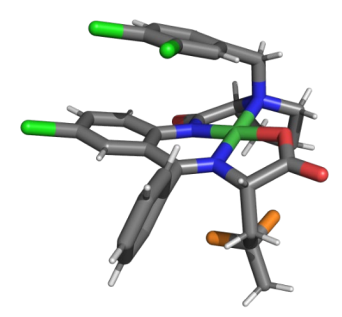

18

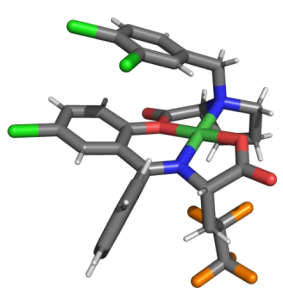

19

Scheme 5: Gram-scale syntheses of fluorinated norvaline variants using the chiral Ni(II) complex 1. Ni(II) Schiff base complexes of DfpGly 18 and PfpGly 19 were further characterized by X-ray crystallographic structure determination.

The alkylated complexes 18 and 19 were isolated on a gram-scale in good yields and great diastereomeric purities (>90\%de) and could be analyzed by X-ray diffraction (Scheme 5). The final hydrolysis of the $\mathrm{Ni}$ (II) complex was carried out using the previously reported conditions. Both Fmoc protected amino acids (DfpGly 6 and PfpGly 7) were obtained in good yields and with high enantiomeric excess. To the best of our knowledge, the application of Fmoc-PfpGly 7 in the context of peptide chemistry has not yet been reported in the literature. To explore the properties of this highly fluorinated amino acid, we examined the hydrophobicity and $\alpha$-helix propensity for this and all other fluorinated amino acids described in this work.

Hydrophobicity and helix propensity of fluorinated amino acids We used an HPLC-based assay which is established in our laboratory to describe the hydrophobicity of PfpGly 7 (Figure 
1, a). ${ }^{31,32}$ The hydrophobicity of fluorinated $\mathrm{Abu}$ and valine analogs has been discussed thoroughly in previous publications. ${ }^{31}$ Interestingly, the results for the fluorinated norvaline and isoleucine variants fit perfectly into prior results. Partial fluorination of the norvaline side chains (DfpGly 6) lowers the hydrophobicity of the molecule, compared to the non-fluorinated norvaline, while pentafluorination strongly increases the retention time of PfpGly 7 which underlines its hydrophobicity (Figure 1, a).

a.

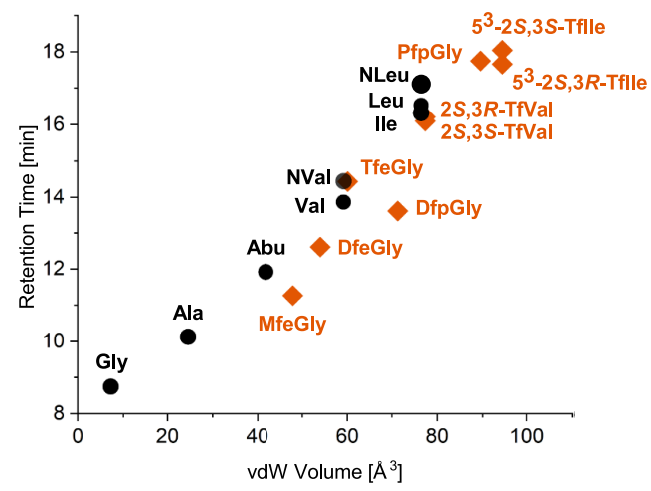

d.

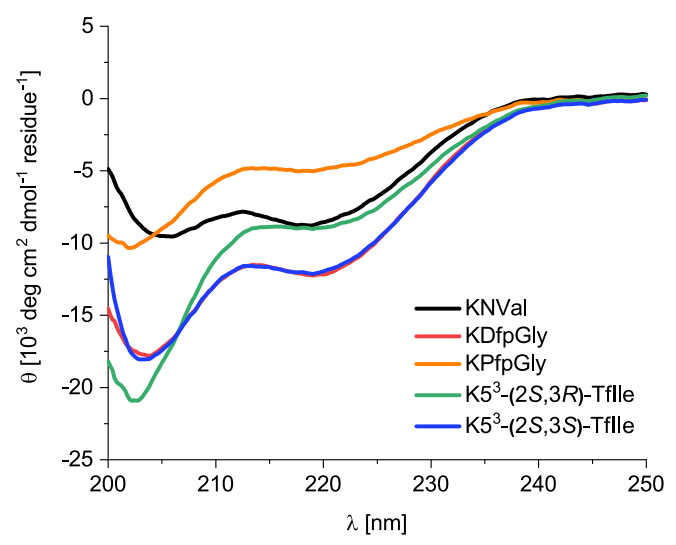

b.

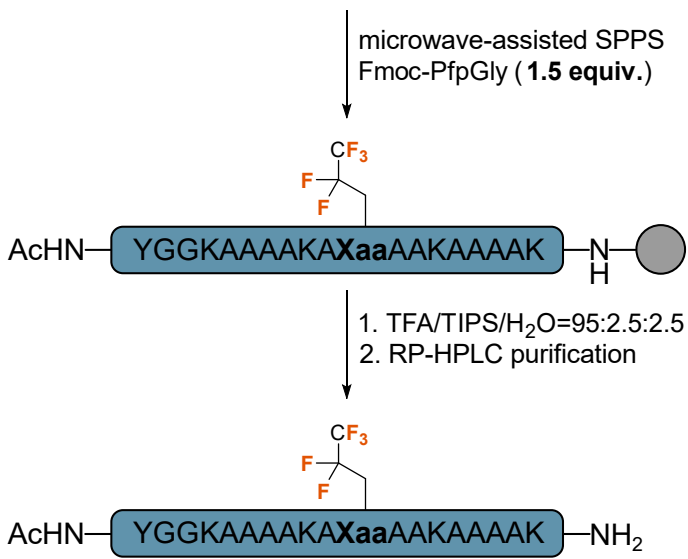

C.

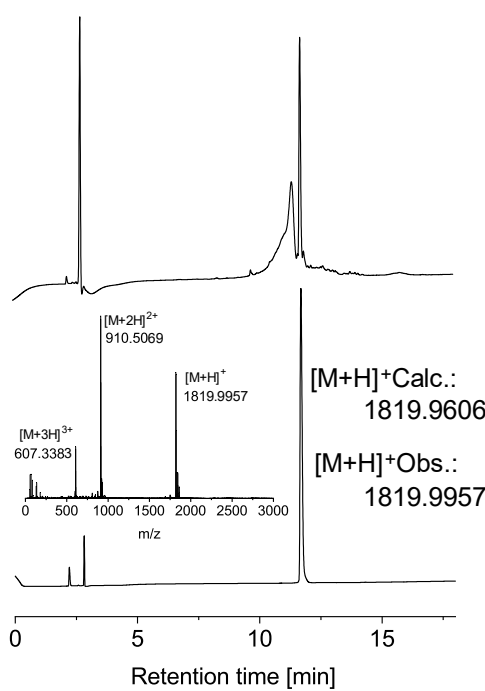

Figure 1: a. Retention times of amino acids plotted against the vdW volume of the side chains. b. SPPS of KPfpGly using only 1.5 equiv. of the pentafluorinated amino acid. c. HPLC chromatogram of the crude peptide after full cleavage (top) and HPLC chromatogram with the corresponding HRMS spectrum of the purified KPfpGly. d. CD spectra of KXaa peptides at $0{ }^{\circ} \mathrm{C}$.

As expected, in the case of the fluorinated isoleucines, the fluorination of the side chains increases the hydrophobicity of the molecules. In contrast to TfVal 4, the TfIle 5 diastereomers show a larger difference in their retention times. This clearly demonstrates that the influence of 
fluorine on the hydrophobicity of amino acids depends on several factors, such as the degree of fluorination, position of fluorination, and the stereochemistry within the side chain. ${ }^{33,34}$

For the determination of the $\alpha$-helix propensity, we used a circular dichroism (CD)-based assay which was introduced by Cheng et al. ${ }^{35}$ The approach is based on a monomeric $\alpha$-helical peptide with the sequence Ac-YGGKAAAAKAXaaAAKAAAAK-NH 2 (KXaa). The amino acids to be studied regarding their structural properties are introduced into the peptide sequence at the Xaa position. Afterwards, corresponding $\alpha$-helix propensity values can be calculated from the CD data. Our laboratory further expanded the data published by Cheng et al. continuously with new fluorinated amino acids. ${ }^{31}$

Table 3: Mean residue ellipticity $(\theta[222 \mathrm{~nm}])$ and fraction helix $\left(f_{\text {helix }}\right)$ values for a series of canonical and fluorinated amino acids. Entry 1 was adapted from Cheng et al. ${ }^{35}$ and entries 2-8 were taken from Gerling et al. ${ }^{31}$

\begin{tabular}{ccccc}
\hline Entry & $\begin{array}{c}\text { Fluorinated } \\
\text { Amino Acid }\end{array}$ & $\boldsymbol{\Theta}[\mathbf{2 2 2} \mathbf{~ n m}]$ & $\boldsymbol{f}_{\text {helix }}$ & $\boldsymbol{w}$ \\
\hline $\mathbf{1}$ & Abu & $-18100 \pm 200$ & $0.52 \pm 0.01$ & $1.22 \pm 0.14^{35}$ \\
$\mathbf{2}$ & Leu & $-16814 \pm 379$ & $0.50 \pm 0.01$ & $0.99 \pm 0.09^{31}$ \\
$\mathbf{3}$ & Val & $-13969 \pm 569$ & $0.38 \pm 0.01$ & $0.41 \pm 0.04^{31}$ \\
$\mathbf{4}$ & MfeGly & $-7469 \pm 475$ & $0.48 \pm 0.01$ & $0.87 \pm 0.07^{31}$ \\
$\mathbf{5}$ & DfeGly & $-17457 \pm 465$ & $0.40 \pm 0.02$ & $0.50 \pm 0.06^{31}$ \\
$\mathbf{6}$ & TfeGly & $-13054 \pm 452$ & $0.22 \pm 0.01$ & $0.06 \pm 0.02^{31}$ \\
$\mathbf{7}$ & $(2 S, 3 S)-$ TfVal & $-2685 \pm 526$ & $0.08 \pm 0.02$ & $00^{31}$ \\
$\mathbf{8}$ & $(2 S, 3 R)-$ TfVal & $-3887 \pm 547$ & $0.11 \pm 0.02$ & $00^{31}$ \\
$\mathbf{9}$ & NVal & $-8006 \pm 622$ & $0.23 \pm 0.02$ & $0.09 \pm 0.03$ \\
$\mathbf{1 0}$ & DfpGly & $-11541 \pm 213$ & $0.33 \pm 0.01$ & $0.31 \pm 0.02$ \\
$\mathbf{1 1}$ & PfpGly & $-4621 \pm 23$ & 0.13 & 0 \\
$\mathbf{1 2}$ & $5^{3}$-(2S,3R)-TfIle & $-8575 \pm 223$ & $0.25 \pm 0.01$ & $0.12 \pm 0.01$ \\
$\mathbf{1 3}$ & $5^{3}$-(2S,3S)-TfIle & $-11372 \pm 709$ & $0.33 \pm 0.02$ & $0.30 \pm 0.06$ \\
& & & & $(1 \text { it. } 0.26)^{27}$ \\
\hline
\end{tabular}

In the current work, NVal, DfpGly 6, PfpGly 7, $5^{3}-(2 S, 3 R)-$, and $5^{3}-(2 S, 3 S)$-TfIle 5 were analyzed using this approach (Table 3, Entries 9-13). The corresponding peptide sequences were synthesized by microwave-assisted SPPS. We were pleased to see, that PfpGly 7 could be incorporated using standard coupling conditions despite the highly fluorinated side chain (Figure 1, b). The trends for the helical propensity based on the degree of fluorination of NVal 
are similar to those observed in the fluorination series of Abu (Table 2, Entries 1, 4-6). In this case, however, partial fluorination even increases the helical propensity of the amino acid (Table 2, Entry 10). As expected, pentafluorination leads to a loss of $\alpha$-helix propensity compared to the non-fluorinated analog due to the increased size of the side chain and higher hydrophobicity (Table 2, Entry 11). The comparison between the values for TfVal 4 and Tflle 5 shows that the fluorinated analogs of Ile can stabilize the helix more effectively. This could be explained by the proximity of the $\mathrm{CF}_{3}$-group to the backbone of the peptide. In the case of TfIle 4, the sterically demanding fluorinated group is more distant from the backbone, which seems to allow a higher helical propensity. Finally, the results illustrate that $\alpha$-helix propensities of fluorinated amino acids cannot only be explained by their hydrophobicity. ${ }^{33,34}$ TfIle $\mathbf{5}$ diastereomers exhibit the highest hydrophobicity values of all fluorinated amino acids discussed in this work. However, the corresponding $\boldsymbol{w}$ values are higher than in the case of TfVal 4 indicating that other factors, such as proximity to the backbone and stereochemistry must contribute to the structural propensity of an individual amino acid.

\section{Conclusion}

We established a gram-scale synthesis for a series of different fluorinated amino acids. The syntheses described in this work are facile and can be carried out on a decagram-scale. All eight described fluorinated amino acids were synthesized from the same starting material in only two steps. The Fmoc protected amino acids were isolated with high enantiomeric purity ( $>94 \% \mathrm{ee})$. We also described a two-steps synthesis to obtain the desired linear and branched alkyl iodides as amino acid side chain precursors from the corresponding fluorinated alcohols on a gram-scale with good overall yields. Furthermore, to the best of our knowledge, we are the first to introduce the first synthesis of peptides containing the pentafluorinated variant of norvaline (Fmoc-PfpGly 7) using microwave-assisted SPPS conditions. Finally, the hydrophobicity and the $\alpha$-helix propensity of the synthesized amino acids were characterized using an HPLC-based assay and circular dichroism showing how the two intrinsic properties depend on several parameters such as the degree of fluorination, the fluorination position within the side chain, and the stereochemistry. This work provides a unified approach to a range of fluorinated amino acids, which vary widely in both sterics and degree of fluorination. The presented access to fluorinated amino acids on a gram-scale facilitates the utilization of these compounds in peptide chemistry and opens the door to their inclusion into biomaterial development. 


\section{Experimental Section}

\section{General information}

All air- and hydrolysis-sensitive reactions were carried out under exclusion of air and water in Schlenk-vessels at a Schlenk unit/oil pump vacuum under nitrogen atmosphere. The stated reaction temperatures refer to the temperatures of the silicone oil heating bath. All reactions were stirred with an electric magnetic stirrer. ${ }^{1} \mathbf{H}-,{ }^{13} \mathbf{C}$ - and ${ }^{19} \mathbf{F}-\mathbf{N M R}$ spectra were recorded at room temperature using a JEOL ECP 600 (JEOL, Tokyo, Japan). The depiction and analysis of the spectra was carried out with the program MestReNova Version 10.0.0 (Mestrelab Research S. L., Santiago de Compostela, Spain). The chemical shifts are given in parts per million (ppm). The ${ }^{1} \mathrm{H}$ - and ${ }^{13} \mathrm{C}$-NMR chemical shifts were referenced against the specific internal solvent residual peaks $\left(\mathrm{CDCl}_{3}, \mathrm{CD}_{3} \mathrm{OD}\right)$ and given to trimethylsilane as internal standard $(\delta=$ $0.00 \mathrm{ppm}$ ). High-resolution mass spectra (HRMS) of the synthesized compounds were obtained on an Agilent 6220 ESI-TOF MS instrument (Agilent Technologies, Santa Clara,CA, USA). The dissolved samples were injected directly into the spray chamber using a syringe pump with flow rates of 10 to $40 \mu \mathrm{L} / \mathrm{min}$. A spray voltage of $4 \mathrm{kV}$ was used and the desolvation gas was set to 15 psi. All other parameters were optimized for maximal abundance of $[\mathrm{M}+\mathrm{H}]^{+}$, $[\mathrm{M}+\mathrm{Na}]^{+}$or $[\mathrm{M}+\mathrm{K}]^{+}$. High-resolution electron ionization mass spectra (HR-EI-MS) were measured on a MAT 711 (Varian MAT, Bremen). Electron energy for EI was set to $70 \mathrm{eV}$. Infrared spectra (IR) were recorded on an ALPHA II (Bruker, Billerica, United States) spectrometer. Characteristic absorption bands are given in wavenumbers. Elemental analysis (EA) measurements were carried out on a VARIO EL (Elementar, Langenselbold, Germany). Qualitative thin-layer chromatography (TLC) was performed on silica gel $60 \mathrm{~F}_{254}$ coated with aluminium plates from Merck. The analytes were indicated by irradiation of the TLC plates with UV light $(\lambda=254 \mathrm{~nm})$ and UV absorption by the analyte. For flash chromatography, silica gel $60 \mathrm{M}$ from Macherey-Nagel of grain size of 40-63 $\mu \mathrm{m}$ was used. The respective conditions are given in the form " $(\mathrm{A}: \mathrm{B}=\mathrm{a}: \mathrm{b})$ ", where $\mathrm{A}: \mathrm{B}$ indicates the solvents used as mobile phase and $a: b$ their volume ratio. Purity of synthesized Fmoc-protected amino acids was determined by analytical high performance liquid chromatography (HPLC) on a Primaide ${ }^{\mathrm{TM}}$ DAD system (VWR/Hitachi, Germany). The system works with a low-pressure gradient containing a HPLC pump (1110) with a 6-channel solvent degaser, an organizer, an autosampler (1210) with a $100 \mu \mathrm{L}$ sample loop, a column oven (1310) and a diode array detector (1430). A Kinetex ${ }^{\mathrm{TM}} \mathrm{C} 18$

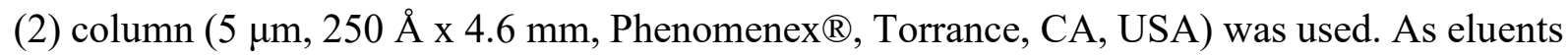


$\mathrm{H}_{2} \mathrm{O}$ and $\mathrm{MeCN}$, both containing $0.1 \%$ (v/v) TFA were applied. For chiral analytical HPLC, a CHIRALPAK ${ }^{\circledR}$ ZWIX(-) column $((R, R)$-ACHSA immobilized on $3 \mu \mathrm{m}$ silica gel, $250 \mathrm{x}$ $4 \mathrm{~mm}$, Chiral Technologies Europe, Illkirch Cedex, France) was used. As eluents, $\mathrm{MeCN} / \mathrm{MeOH} / \mathrm{H}_{2} \mathrm{O}$ with $50 \mathrm{mM}$ formic acid and $25 \mathrm{mM}$ diethylamine were used. A flow rate of $1.0 \mathrm{~mL} / \mathrm{min}$ was used, and the column was heated to $24^{\circ} \mathrm{C}$. The UV-detection of the Fmocprotected amino acids occurred at $280 \mathrm{~nm}$. The data were analyzed with EZChrom ELITE software (version 3.3.2 SP2, Agilent). HPLC-based hydrophobicity assay was carried out on a LaChrom-ELITE-HPLC-System from VWR International Hitachi. The System contains an organizer, two HPLC-pumps (L-2130) with solvent degaser, an autosampler (L-2200), a diode array flow detector (L-2455), a fluorescence detector (L-2485) and a high-pressure gradient mixer. The data were analyzed with EZ Chrom ELITE software (version 3.1.7). A Capcell C18 column (Shiseido, Osaka Soda Co., LTD., Osaka, Japan) was used. As eluents, $\mathrm{H}_{2} \mathrm{O}$ and $\mathrm{MeCN}$, both containing $0.1 \%(\mathrm{v} / \mathrm{v})$ TFA, were applied. A flow rate of $1 \mathrm{~mL} / \mathrm{min}$ was used and the UV-detection occurred at $220 \mathrm{~nm}$. Purification of synthesized peptides was performed on a Knauer low-pressure HPLC system (Knauer GmbH, Berlin, Germany) sold by VWR (Darmstadt, Germany), comprising a LaPrep Sigma preparative pump (LP1200), a ternary lowpressure gradient, a dynamic mixing chamber, a 6-port-3-channel injection valve with an automated preperative $10 \mathrm{~mL}$ sample loop, a LaPrep Sigma standard 1-channel-UV-detector (LP3101), a flow cell with $0.5 \mathrm{~mm}$ thickness and a 16-port LaPrep Sigma fractionation valve (LP2016). A Kinetex RPC18 endcapped ( $5 \mu \mathrm{M}, 100 \AA$, 250 x $21.2 \mathrm{~mm}$, Phenomenex ${ }^{\circledR}$, USA) HPLC-column was used. A Security GuardTM PREP Cartridge Holder Kit (21.20 mm, ID, Phenomenex $\left.{ }^{\circledR}, \mathrm{USA}\right)$ served as pre-column. As eluents water and $\mathrm{MeCN}$, both containing $0.1 \%$ (v/v) TFA were applied. HPLC runs were performed with a flow rate of $15 \mathrm{~mL} / \mathrm{min}$, UVdetection occurred at $220 \mathrm{~nm}$ for respective peptides. Deionized water was obtained using a Milli-Q Advantage ${ }^{\circledR}$ A10 Ultrapure Water Purification System (Millipore ${ }^{\circledR}$, Billerica, MA, USA). Other chemicals were used without further purification and purchased from commercial sources.

\section{X-ray diffractometry}

Chiral $\mathrm{Ni}$ (II) complexes were crystallized by slow evaporation from $\mathrm{MeOH}(3 \mathrm{mg} / \mathrm{mL})$. Low temperature x-ray diffraction data were acquired on a Bruker D8 Venture diffractometer fitted with a PhotonII CMOS detector. Crystal structures were solved using SHELXT and refined with SHELXL-2018. 


\section{Peptide synthesis}

All peptides were synthesized according to standard Fmoc-chemistry on a $0.05 \mathrm{M}$ scale using preloaded Fmoc-glycine Wang $(0.19 \mathrm{mmol} / \mathrm{g})$ resin on a Liberty Blue microwave-assisted peptide synthesizer (CEM GmbH, Matthews, USA). Fmoc deprotection was performed using 10\% piperazine and $0.1 \mathrm{M} \mathrm{HOBt}(\mathrm{w} / \mathrm{v})$ in EtOH:NMP $=1: 9\left(1 \mathrm{~min}, 90^{\circ} \mathrm{C}\right)$. Peptide couplings were carried out using 0.5 M DIC/0.5 M Oxyma/0.05 M DIPEA in DMF. The standard Fmocamino acids were coupled using 5 equiv. of amino acid $\left(30 \mathrm{~s}, 75^{\circ} \mathrm{C}\right)$. Fluorinated amino acids were introduced using only 1.5 equiv. of the amino acid with prolonged coupling times $(2 \mathrm{~min}$, $90{ }^{\circ} \mathrm{C}$ ). For acetylation of the $N$-terminus of the synthesized peptides, the resin was treated with $\mathrm{Ac}_{2} \mathrm{O} / \mathrm{DIPEA} / \mathrm{DMF}=1: 1: 8(3 \mathrm{x} 5 \mathrm{~mL}, 10 \mathrm{~min})$. Peptides were cleaved from the resin using TFA/TIPS/ $\mathrm{H}_{2} \mathrm{O}=95: 2.5: 2.5$ ( $5 \mathrm{~mL}, 2 \mathrm{~h}$ ). The synthesized peptides were purified by reversedphase preparative HPLC and characterized by ESI-ToF HRMS. To lyophilize the synthesized peptides a laboratory freeze dryer ALPHA 1-2 LD (Christ Gefriertrocknungsanlagen GmbH, Osterode am Harz, Germany) was used.

\section{$\alpha$-helix propensity}

Circular dichroism spectra were recorded with a Jasco J-810 spectropolarimeter using a quartz cuvette of $1 \mathrm{~mm}$ path length at $0{ }^{\circ} \mathrm{C}$. For temperature control, a JACSO PFD-350S Peltier element was used. $\mathrm{CD}$ measurements were performed in $1 \mathrm{M} \mathrm{NaCl}, 1 \mathrm{~mm}$ sodium phosphate, $1 \mathrm{mM}$ sodium citrate, and $1 \mathrm{mM}$ sodium borate $(\mathrm{pH}=7)$ at peptide concentrations of 30,50 , and $80 \mathrm{~mm}$. Each reported $\mathrm{CD}$ value represents the mean of at least three independent measurements. For each spectrum, the data was obtained at $0.2 \mathrm{~nm}$ intervals, $2 \mathrm{~nm}$ bandwidth, and $2 \mathrm{~s}$ response time. The nitrogen flow rate was set to $3.5 \mathrm{~L} / \mathrm{min}$. The spectra were recorded in the far-UV range $(250-200 \mathrm{~nm})$ and the signals of the blank solvent were subtracted. Ellipticity $\theta_{\text {Obs }}$ was normalized into molar ellipticity per residue using $[\theta]=\theta_{\mathrm{Obs}} / 100001 \mathrm{~N}$ c with $1=$ path length $[\mathrm{cm}], \mathrm{N}=$ number of residues, $\mathrm{c}=$ concentration $\left[\mathrm{mol} \mathrm{L}^{-1}\right]$. The fractional helical content of peptide $\left(f_{\text {helix }}\right)$ was calculated from $[\theta]$ at $222 \mathrm{~nm}$ using $f_{\text {helix }}=[\theta]_{222 \mathrm{~nm}} /(40000(1-$ $2.5 / \mathrm{N})$ ). The helix propensity $w$ of the amino acid at the guest position was calculated from the $\mathrm{f}_{\text {helix }}$ of the corresponding peptide based on modified Lifson-Roig theory. For each amino acid, four different parameters are important: helix propensity $(w)$, nucleation $(v)$, N-terminal capping propensity $(n)$, and C-terminal capping propensity $(c)$. For all residues, $\mathrm{v}$ was set to 0.048 , and $\mathrm{c}$ was set to 1 . For the host amino acids, literature values were used for $w$ and $n$. For the residue in the guest position, $\mathrm{n}$ was set to 1 , and $w$ was calculated numerically. 


\section{Size exclusion chromatography}

Determination of the oligomerization state of KXaa peptides has been carried out using size exclusion chromatography (SEC) in combination with static light scattering (SLS). For the size exclusion analysis, a Superdex ${ }^{\mathrm{TM}}$ Peptide 10/300 GL column (10 x $310 \mathrm{~mm}$, Cytiva) was used connected to a HPLC station (La Chrom, VWR, Hitachi, L-2130). The experiments were performed at a velocity of $0.5 \mathrm{~mL} \mathrm{~min}{ }^{-1}$ in a $10 \mathrm{mM}$ sodium phosphate buffer with $150 \mathrm{mM}$ sodium chloride at $\mathrm{pH}$ 7.4. The sample concentration was between 500 and $600 \mathrm{~mm}$ and the injection volume was $100 \mu \mathrm{L}$. Dawn Heleos 8 light scattering photometer and an Optilab rEX refractive index detector (Wyatt Technology) were used for SLS experiments. Molecular weight values were calculated by using a dn/dc value of $0.185 \mathrm{~mL} \mathrm{~g}^{-1}$. All data were analyzed with ASTRA software version 6.1 (Wyatt Technology).

\section{HPLC-based hydrophobicity assay}

The impact of fluorination on the hydrophobicity of fluorinated amino acids was investigated using a HPLC-based assay established by our group. The Fmoc-protected amino acids were dissolved in $\mathrm{MeCN} / \mathrm{H} 2 \mathrm{O}=4: 6(0.1 \mathrm{mM})$ with $0.1 \% \mathrm{TFA}(\mathrm{v} / \mathrm{v})$ and filtered over a syringe filter with $0.2 \mathrm{~mm}$ pore size. A linear gradient $40 \%$ to $70 \% \mathrm{MeCN}$ in $\mathrm{H}_{2} \mathrm{O}$ was used at room temperature and each measurement was carried out in triplicate. The obtained retention times were plotted against the van der Waals volumes of the corresponding side chains. The van der Waals volumes were calculated according to Zhao et al. ${ }^{36}$

\section{General procedure A: Nonaflation of fluorinated alcohols}

According to M. Hanack and J. Ullmann ${ }^{30}$, the fluorinated alcohol (1.0 equiv.) was dissolved in dry $\mathrm{CH}_{2} \mathrm{Cl}_{2}(3.0 \mathrm{M})$ and $\mathrm{NEt}_{3}\left(1.0\right.$ equiv.) was added at $-40{ }^{\circ} \mathrm{C}$ under a nitrogen atmosphere. Perfluorobutanesulfonyl fluoride (1.375 equiv.) was added dropwise to the reaction solution at $-40 \mathrm{C}$. After the addition, the reaction mixture was allowed to warm up to $23{ }^{\circ} \mathrm{C}$. The reaction solution was stirred at this temperature for $16 \mathrm{~h}$. Subsequently, $\mathrm{CH}_{2} \mathrm{Cl}_{2}$ was removed under reduced pressure. The crude product was purified by distillation. 


\section{General procedure B: Iodination of alkyl nonaflates}

The nonaflate (1.0 equiv.) was dissolved in DMI $(3 \mathrm{M})$ and sodium iodide (1.2 equiv.) was added to the solution. The reaction mixture was stirred at $23{ }^{\circ} \mathrm{C}$ for $24 \mathrm{~h}$. The product was purified by high vacuum distillation $\left(10^{-2} \mathrm{mbar}\right)$ into a cooling trap $\left(-78^{\circ} \mathrm{C}\right)$.

\section{General procedure C: Alkylation of chiral Ni(II) complex using KOH/MeOH}

According to Z. Yin et al. ${ }^{14}$, Ni(II) complex (1.0 equiv.) was dissolved in dry, degassed DMF $(0.2 \mathrm{M})$ under a nitrogen atmosphere. Alkyl iodide (1.05 equiv.) and then $\mathrm{KOH}$ (1.05 equiv.) dissolved in dry, degassed $\mathrm{MeOH}$ were added to the solution at $0{ }^{\circ} \mathrm{C}$. The reaction mixture was stirred at $0{ }^{\circ} \mathrm{C}$ for $2 \mathrm{~h} . \mathrm{H}_{2} \mathrm{O}(3.2 \mathrm{v} / \mathrm{w})$ was added to the solution and the reaction mixture was stirred for $1 \mathrm{~h}$. An additional amount of $\mathrm{H}_{2} \mathrm{O}(1.8 \mathrm{v} / \mathrm{w})$ was added, and the reaction mixture was stirred for another $1 \mathrm{~h}$. The precipitated product was filtered from the reaction mixture. The product was washed with $\mathrm{DMF} / \mathrm{H}_{2} \mathrm{O}=2: 1(1.8 \mathrm{v} / \mathrm{w})$ and then with $\mathrm{H}_{2} \mathrm{O}(2.0 \mathrm{v} / \mathrm{w})$. The product was dried under high vacuum at $60{ }^{\circ} \mathrm{C}$.

\section{General procedure D: Alkylation of chiral Ni(II) complex using NaH}

Ni (II) complex (1.0 equiv.) was dissolved in dry, degassed DMF (0.4 M) under a nitrogen atmosphere. Alkyl iodide (1.05 equiv.) and then $\mathrm{NaH}$ (1.3/2.0 equiv.) were added to the solution at $0{ }^{\circ} \mathrm{C}$. The reaction mixture was stirred at $0{ }^{\circ} \mathrm{C}$ for $2 \mathrm{~h} . \mathrm{H}_{2} \mathrm{O}(3.2 \mathrm{v} / \mathrm{w})$ was added to the solution and the reaction mixture was stirred for $1 \mathrm{~h}$. An additional amount of $\mathrm{H}_{2} \mathrm{O}(1.8 \mathrm{v} / \mathrm{w})$ was added, and the reaction mixture as stirred for another $1 \mathrm{~h}$. The precipitated product was filtered from the reaction mixture. An additional amount of product precipitated from the filtrate after another addition of $\mathrm{H}_{2} \mathrm{O}(2.0 \mathrm{v} / \mathrm{w})$. The combined product was combined and dried under high vacuum at $60{ }^{\circ} \mathrm{C}$.

\section{General procedure E: Hydrolysis and Fmoc-protection}

According to Z. Yin et al., the alkylated Ni (II) complex (1.0 equiv.) was dissolved in dimethoxyethane $(0.3 \mathrm{M})$ and $3 \mathrm{M}$ aqueous $\mathrm{HCl}$ solution (5.0 equiv.) was added. The reaction mixture was stirred for $2 \mathrm{~h}$ at $60^{\circ} \mathrm{C}$. The reaction mixture was cooled to $23^{\circ} \mathrm{C}$ and the precipitated ligand was filtered from the solution. The ligand was washed with $\mathrm{H}_{2} \mathrm{O}(2.0 \mathrm{v} / \mathrm{w})$ 
and the filtrate was concentrated under reduced pressure $(4.0 \mathrm{v} / \mathrm{w})$. An additional amount of the ligand precipitated from the solution. The ligand was filtered and washed with $\mathrm{H}_{2} \mathrm{O}(2.0 \mathrm{v} / \mathrm{w})$. Both fractions of the ligand were combined and dried under high vacuum at $40{ }^{\circ} \mathrm{C}$. $\mathrm{MeCN}$ $(0.5 \mathrm{M})$ and EDTA $\mathrm{Na}_{2}(1.0$ equiv.) were added to the filtrate. The reaction mixture was stirred at $23{ }^{\circ} \mathrm{C}$ for $2 \mathrm{~h}$. The $\mathrm{pH}$ of the solution was adjusted to 7 and subsequently $\mathrm{Na}_{2} \mathrm{CO}_{3}$ (2.0 equiv.) was added to the mixture. FmocOSu (1.0 equiv.) was dissolved in acetone $(0.25 \mathrm{M})$ and added dropwise to the reaction solution. The mixture was stirred at $23{ }^{\circ} \mathrm{C}$ for $16 \mathrm{~h}$. MeCN and acetone were removed under reduced pressure, additional amount of $\mathrm{H}_{2} \mathrm{O}$ was added, and the aqueous solution was washed with $\mathrm{Et}_{2} \mathrm{O}$. The solution was acidified to $\mathrm{pH}=2$ using a $6 \mathrm{M}$ aqueous $\mathrm{HCl}$ solution. The mixture was extracted with EtOAc, the combined organic phases were dried over $\mathrm{Na}_{2} \mathrm{SO}_{4}$, and the solvent was removed under reduced pressure. The crude product was purified by recrystallization from a hexane/EtOAc mixture.

\section{2,2-Difluoropropyl 1,1,2,2,3,3,4,4,4-nonafluorobutane-1-sulfonate (9)}

According to general procedure A, 2,2-difluoropropan-1-ol $(3.84 \mathrm{~g}, 3.3 \mathrm{~mL}, 40.0 \mathrm{mmol}$, 1.0 equiv.) was dissolved in dry $\mathrm{CH}_{2} \mathrm{Cl}_{2}(13 \mathrm{~mL})$, and $\mathrm{NEt}_{3}(4.05 \mathrm{~g}, 5.6 \mathrm{~mL}, 40.0 \mathrm{mmol}$, 1.0 equiv.) and $\mathrm{NfF}\left(16.61 \mathrm{~g}, 9.9 \mathrm{~mL}, 55.0 \mathrm{mmol}, 1.375\right.$ equiv.) were added at $-40{ }^{\circ} \mathrm{C}$ under a nitrogen atmosphere. The desired product was purified by distillation $\left(30 \mathrm{mbar}, 70{ }^{\circ} \mathrm{C}\right)$ and obtained as colorless liquid (7.97 g, 53\%). ${ }^{1} \mathrm{H}$ NMR (600 MHz, $\left.\mathrm{CDCl}_{3}\right) \delta 4.55$ (t, $J=10.8 \mathrm{~Hz}$, 2H), $1.76(\mathrm{t}, J=18.8 \mathrm{~Hz}, 3 \mathrm{H}) .{ }^{13} \mathrm{C}\left\{{ }^{1} \mathrm{H}\right\} \mathrm{NMR}\left(101 \mathrm{MHz}, \mathrm{CDCl}_{3}\right) \delta 118.8(\mathrm{t}, J=241.7 \mathrm{~Hz})$, 118.0, 116.1, 114.6, 109.8, 74.0 (t, $J=36.7 \mathrm{~Hz}), 20.6$ (t, $J=25.4 \mathrm{~Hz}) .{ }^{19} \mathrm{~F}$ NMR $(376 \mathrm{~Hz}$, $\left.\mathrm{CDCl}_{3}\right), \delta-80.6(\mathrm{t}, J=9.7 \mathrm{~Hz}),-99.4(\mathrm{dtd}, J=29.1,18.8,10.8 \mathrm{~Hz}),-110.1,-121.2,-125.8$. ATR-FTIR (neat) 1422, 1400, 1353, 1293, 1223, 1193, 1141, 1036, 1005, 980, 933, 913, 881, 849, 792, 749, 735, 699, 686, 653, 587, 532, $503 \mathrm{~cm}^{-1}$. HRMS (EI, $\left.70 \mathrm{eV}\right) \mathrm{m} / \mathrm{z}$ : [M] ${ }^{+} \mathrm{Calcd}_{\text {for }}$ $\mathrm{C}_{7} \mathrm{H}_{5} \mathrm{~F}_{11} \mathrm{O}_{3} \mathrm{~S} 377.9784$; Found 378.0275.

\section{1,1,1-Trifluoropropan-2-yl 1,1,2,2,3,3,4,4,4-nonafluorobutane-1-sulfonate (12)}

According to general procedure A, 1,1,1-trifluoropropan-2-ol (21.54 g, $17.1 \mathrm{~mL}, 188.8 \mathrm{mmol}$, 1.0 equiv.) was dissolved in dry $\mathrm{CH}_{2} \mathrm{Cl}_{2}(63 \mathrm{~mL})$, and $\mathrm{NEt}_{3}(19.10 \mathrm{~g}, 26.2 \mathrm{~mL}, 188.8 \mathrm{mmol}$, 1.0 equiv.) and $\mathrm{NfF}$ (78.42 g, $46.7 \mathrm{~mL}, 259.6 \mathrm{mmol}, 1.375$ equiv.) were added at $-40{ }^{\circ} \mathrm{C}$ under a nitrogen atmosphere. The desired product was purified by distillation $\left(30 \mathrm{mbar}, 62{ }^{\circ} \mathrm{C}\right)$ and obtained as colorless liquid (46.60 g, 62\%). ${ }^{1} \mathrm{H}$ NMR (600 MHz, $\left.\mathrm{CDCl}_{3}\right) \delta 5.14(\mathrm{t}, J=12.2$, 
$6.1 \mathrm{~Hz}, 1 \mathrm{H}), 1.65(\mathrm{~d}, J=6.1 \mathrm{~Hz}, 3 \mathrm{H}) .{ }^{13} \mathrm{C}\left\{{ }^{1} \mathrm{H}\right\} \mathrm{NMR}\left(101 \mathrm{MHz}, \mathrm{CDCl}_{3}\right) \delta 122.1(\mathrm{t}, J=241.7)$, 117.9, 116.3, 114.3, 109.8, 79.1 (q, $J=35.8 \mathrm{~Hz}), 14.6 .{ }^{19} \mathrm{~F}$ NMR $\left(376 \mathrm{~Hz}, \mathrm{CDCl}_{3}\right), \delta-78.7$, $80.58(\mathrm{t}, J=9.7 \mathrm{~Hz}),-109.58--111.30(\mathrm{~m}),-120.89,-125.82$. ATR-FTIR (neat) 1428, 1283, 1238, 1227, 1195, 1170, 1142, 1062, 1036, 1010, 939, 797, 786, 737, 700, 651, 590, $525 \mathrm{~cm}^{-1}$. HRMS (EI, $70 \mathrm{eV}$ ) m/z: $\left[\mathrm{C}_{4} \mathrm{~F}_{9} \mathrm{SO}_{3} \mathrm{CHCF}_{3}\right]^{+}$Calcd for $\mathrm{C}_{4} \mathrm{~F}_{9} \mathrm{SO}_{3} \mathrm{CHCF}_{3}$ 380.9455; Found 380.9859 .

\section{2,2-Difluoro-1-iodopropane (10)}

According to general procedure B, difluoropropyl nonaflate $(7.87 \mathrm{~g}, 20.8 \mathrm{mmol}, 1.0$ equiv.) was dissolved in DMI (7 mL) and sodium iodide (3.75 g, $25.0 \mathrm{mmol}, 1.2$ equiv.) was added to the solution. The product was obtained as colorless liquid (3.90 g, 91\%). ${ }^{1} \mathrm{H}$ NMR (600 MHz, $\left.\mathrm{CDCl}_{3}\right) \delta 3.4(\mathrm{t}, J=13.9 \mathrm{~Hz}, 2 \mathrm{H}), 1.8(\mathrm{t}, J=17.8 \mathrm{~Hz}, 3 \mathrm{H}) .{ }^{13} \mathrm{C}\left\{{ }^{1} \mathrm{H}\right\} \mathrm{NMR}\left(101 \mathrm{MHz}, \mathrm{CDCl}_{3}\right)$ $\delta 120.4(\mathrm{t}, J=239.8 \mathrm{~Hz}), 22.6(\mathrm{t}, J=27.2 \mathrm{~Hz}), 4.9(\mathrm{t}, J=32.0 \mathrm{~Hz}) .{ }^{19} \mathrm{~F} \mathrm{NMR}\left(376 \mathrm{~Hz}, \mathrm{CDCl}_{3}\right)$ $\delta-87.5$ - -87.7 (m). ATR-FTIR (neat) 1419, 1390, 1262, 1249, 1220, 1202, 1137, 1113, 1052 , 958, 915, 816, 785, 647, 544, $497 \mathrm{~cm}^{-1}$. HRMS (EI, $\left.70 \mathrm{eV}\right) \mathrm{m} / z$ : $[\mathrm{M}]^{+}$Calcd for $\mathrm{C}_{3} \mathrm{H}_{5} \mathrm{~F}_{2} \mathrm{I}$ 205,9404; Found 205.9566.

\section{1,1,1-Trifluoro-2-iodopropane (13)}

According to general procedure B, trifluoro-iso-propyl nonaflate $(46.37 \mathrm{~g}, 117.1 \mathrm{mmol}$, 1.0 equiv.) was dissolved in DMI (39 mL) and sodium iodide (21.1 g, $140.5 \mathrm{mmol}, 1.2$ equiv.) was added to the solution. The product was obtained as colorless liquid $(24.90 \mathrm{~g}, 95 \%) .{ }^{1} \mathrm{H}$ NMR $\left(600 \mathrm{MHz} \mathrm{CDCl}_{3}\right) \delta 4.25(\mathrm{dq}, J=7.8,7.4 \mathrm{~Hz}, 1 \mathrm{H}), 1.96(\mathrm{~d}, J=7.6 \mathrm{~Hz}, 3 \mathrm{H}) .{ }^{13} \mathrm{C}\left\{{ }^{1} \mathrm{H}\right\}$ NMR $\left(101 \mathrm{MHz}, \mathrm{CDCl}_{3}\right) \delta 124.8$ (q, $\left.J=276.2 \mathrm{~Hz}\right), 21.8,14.1$ (q, $\left.J=35.8 \mathrm{~Hz}\right) .{ }^{19} \mathrm{~F}$ NMR $\left(376 \mathrm{~Hz}, \mathrm{CDCl}_{3}\right) \delta-71.5(\mathrm{~d}, J=7.8 \mathrm{~Hz}$ ). ATR-FTIR (neat) 1453, 1343, 1258, 1201, 1165, 1101, 1069, 1037, 973, $647 \mathrm{~cm}^{-1}$. HRMS (EI-TOF) $\mathrm{m} / \mathrm{z}$ : [M] ${ }^{+}$Calcd for $\mathrm{C}_{3} \mathrm{H}_{4} \mathrm{~F}_{3} \mathrm{I}$ 223.9310; Found 223.9519 .

\section{Ni(II)-Schiff base complex of MfeGly (14)}

According to general procedure C, Ni(II) complex (20.00 g, $33.2 \mathrm{mmol}, 1.0$ equiv.) was dissolved in dry, degassed DMF $(200 \mathrm{~mL})$ under a nitrogen atmosphere. First alkyl iodide (6.06 g, $2.8 \mathrm{~mL}, 34.8 \mathrm{mmol}, 1.05$ equiv.) and then $\mathrm{KOH}(2.00 \mathrm{~g}, 34.8 \mathrm{mmol}, 1.05$ equiv.) 
dissolved in dry, degassed $\mathrm{MeOH}(18 \mathrm{~mL})$ were added to the solution at $0{ }^{\circ} \mathrm{C}$ and the mixture was stirred at $0{ }^{\circ} \mathrm{C}$ for $2 \mathrm{~h}$. The product was obtained as orange solid (16.20 g, 75\%). ${ }^{1} \mathrm{H}$ NMR $\left(600 \mathrm{MHz}, \mathrm{CD}_{3} \mathrm{OD}\right) \delta 8.8(\mathrm{~d}, J=2.1 \mathrm{~Hz}, 1 \mathrm{H}), 8.2(\mathrm{dd}, J=8.2,2.1 \mathrm{~Hz}, 1 \mathrm{H}), 8.0(\mathrm{~d}, J=9.3 \mathrm{~Hz}$, 1H), $7.6(\mathrm{td}, J=7.6,0.8 \mathrm{~Hz}, 1 \mathrm{H}), 7.6(\mathrm{tt}, J=7.6,1.3 \mathrm{~Hz}, 1 \mathrm{H}), 7.5-7.5(\mathrm{~m}, 1 \mathrm{H}), 7.5(\mathrm{~d}, J=$ $8.2 \mathrm{~Hz}, 1 \mathrm{H}), 7.4(\mathrm{dt}, J=7.8,1.7 \mathrm{~Hz}, 1 \mathrm{H}), 7.1(\mathrm{dd}, J=9.3,2.6 \mathrm{~Hz}, 1 \mathrm{H}), 7.0(\mathrm{~d}, J=7.8 \mathrm{~Hz}, 1 \mathrm{H})$, $6.5(\mathrm{~d}, J=2.6 \mathrm{~Hz}, 1 \mathrm{H}), 4.9-4.6(\mathrm{~m}, 2 \mathrm{H}), 4.2(\mathrm{~d}, J=12.6 \mathrm{~Hz}, 1 \mathrm{H}), 4.0(\mathrm{dd}, J=8.2,3.7 \mathrm{~Hz}$, $1 \mathrm{H}), 3.6-3.5(\mathrm{~m}, 2 \mathrm{H}), 3.4-3.3(\mathrm{~m}, 2 \mathrm{H}), 2.7-2.5(\mathrm{~m}, 2 \mathrm{H}), 2.3-2.1(\mathrm{~m}, 3 \mathrm{H}), 2.1-2.0(\mathrm{~m}$, 1H). ${ }^{13} \mathrm{C}\left\{{ }^{1} \mathrm{H}\right\}$ NMR $\left(101 \mathrm{MHz}, \mathrm{CD}_{3} \mathrm{OD}\right) \delta 181.3,180.1,171.3,140.6,136.6,133.3,133.0$, 132.7, 132.7, 131.9, 131.7, 131.1, 130.8, 130.2, 129.2, 129.1, 127.8, 127.6, 127.0, 125.5, 124.2, $79.6(\mathrm{~d}, J=165.7 \mathrm{~Hz}), 71.4,67.5,62.6,58.3,34.8(\mathrm{~d}, J=19.8 \mathrm{~Hz}), 30.6,23.0 .{ }^{19} \mathrm{~F}$ NMR $\left(376 \mathrm{~Hz}, \mathrm{CD}_{3} \mathrm{OD}\right), \delta-218.3$ - -218.6 (m). ATR-FTIR (neat) 1682, 1621, 1597, 1588, 1538, 1463, 1443, 1396, 1356, 1325, 1316, 1253, 1228, 1165, 1116, 1077, 1029, 927, 918, 893, 879, 816, 723, 706, 690, 666, 644, 591, 517, 507, 496, 464, 445, $421 \mathrm{~cm}^{-1}$. HRMS (ESI-TOF) $\mathrm{m} / \mathrm{z}$ : $[\mathrm{M}+\mathrm{Na}]^{+}$Calcd for $\mathrm{C}_{29} \mathrm{H}_{25} \mathrm{Cl}_{3} \mathrm{FN}_{3} \mathrm{NiO}_{3}$ 668.0197; Found 668.0186. Anal Calcd for $\mathrm{C}_{29} \mathrm{H}_{25} \mathrm{Cl}_{3} \mathrm{FN}_{3} \mathrm{NiO}_{3}$ : C, 53.79; H, 3.89; N, 6.49. Found: C, 55.39; H, 4.05; N, 6.52.

\section{Ni(II)-Schiff base complex of DfeGly (15)}

According to general procedure C, Ni(II) complex (20.00 g, $33.2 \mathrm{mmol}, 1.0$ equiv.) was dissolved in dry, degassed DMF $(200 \mathrm{~mL})$ under a nitrogen atmosphere. First alkyl iodide (6.68 g, $3.1 \mathrm{~mL}, 34.8 \mathrm{mmol}, 1.05$ equiv.) and then $\mathrm{KOH}$ (2.00 g, $34.8 \mathrm{mmol}, 1.05$ equiv.) dissolved in $\mathrm{MeOH}(18 \mathrm{~mL})$ were added to the solution at $0{ }^{\circ} \mathrm{C}$ and the mixture was stirred at $0{ }^{\circ} \mathrm{C}$ for $2 \mathrm{~h}$. The product was obtained as orange solid $(16.1 \mathrm{~g}, 73 \%) .{ }^{1} \mathrm{H}$ NMR $(600 \mathrm{MHz}$, $\left.\mathrm{CDCl}_{3}\right) \delta 8.9(\mathrm{~s}, 1 \mathrm{H}), 8.1(\mathrm{~d}, J=9.3 \mathrm{~Hz}, 1 \mathrm{H}), 7.8-7.7(\mathrm{~m}, 1 \mathrm{H}), 7.6-7.4(\mathrm{~m}, 3 \mathrm{H}), 7.4-7.3(\mathrm{~m}$, $1 \mathrm{H}), 7.3-7.2(\mathrm{~m}, 1 \mathrm{H}), 7.1(\mathrm{~d}, 1 \mathrm{H}), 6.9-6.8(\mathrm{~m}, 1 \mathrm{H}), 6.6(\mathrm{~s}, 1 \mathrm{H}), 6.1(\mathrm{t}, J=55.7 \mathrm{~Hz}, 1 \mathrm{H}), 4.3$ $(\mathrm{d}, J=12.6 \mathrm{~Hz}, 1 \mathrm{H}), 4.1-4.0(\mathrm{~m}, 1 \mathrm{H}), 3.6-3.4(\mathrm{~m}, 2 \mathrm{H}), 3.4-3.3(\mathrm{~m}, 1 \mathrm{H}), 3.2(\mathrm{~d}, J=12.7$ $\mathrm{Hz}, 1 \mathrm{H}), 2.8-2.6(\mathrm{~m}, 1 \mathrm{H}), 2.6-2.5(\mathrm{~m}, 1 \mathrm{H}), 2.5-2.3(\mathrm{~m}, 1 \mathrm{H}), 2.2(\mathrm{~d}, J=13.2 \mathrm{~Hz}, 1 \mathrm{H}), 2.1-$ $2.0(\mathrm{~m}, 2 \mathrm{H}) .{ }^{13} \mathrm{C}\left\{{ }^{1} \mathrm{H}\right\}$ NMR $\left(101 \mathrm{MHz}, \mathrm{CDCl}_{3}\right) \delta 180.1,177.9,171.7,140.9,134.9,133.7$, 133.7, 133.5, 132.9, 132.6, 132.4, 131.2, 130.7, 130.0, 129.7, 129.7, 127.2, 127.2, 127.0, 126.0, 124.3, $114.6(\mathrm{t}, J=240.1 \mathrm{~Hz}), 71.4,63.2,58.6,38.7(\mathrm{t}, J=23.1 \mathrm{~Hz}), 30.9,29.8,23.8 .{ }^{19} \mathrm{~F} \mathrm{NMR}$ $\left(376 \mathrm{~Hz}, \mathrm{CDCl}_{3}\right), \delta-114.0$ (dddd, $\left.J=287.8,55.8,15.0,9.9 \mathrm{~Hz}\right),-116.0$ (dddd, $J=287.8,55.7$, 23.9, 13.7 Hz). ATR-FTIR (neat) 1678, 1639, 1581, 1527, 1458, 1443, 1395, 1337, 1311, 1241, 1163, 1119, 1094, 1055, 1030, 917, 892, 872, 832, 819, 722, 707, 691, 684, 666, 597, 539, 516, 464, 439, $421 \mathrm{~cm}^{-1}$. HRMS (ESI-TOF) $\mathrm{m} / z$ : $[\mathrm{M}+\mathrm{H}]^{+}$Calcd for $\mathrm{C}_{29} \mathrm{H}_{24} \mathrm{Cl}_{3} \mathrm{~F}_{2} \mathrm{~N}_{3} \mathrm{NiO}_{3} 664.0285$; 
Found 664.0301. Anal Calcd for $\mathrm{C}_{29} \mathrm{H}_{24} \mathrm{Cl}_{3} \mathrm{~F}_{2} \mathrm{~N}_{3} \mathrm{NiO}_{3}$ : C, 52.33; H, 3.63; N, 6.31. Found: C, $55.79 ; \mathrm{H}, 4.40 ; \mathrm{N}, 6.45$.

\section{Ni(II)-Schiff base complex of DfpGly (18)}

According to general procedure D, Ni (II) complex (7.31 g, $12.2 \mathrm{mmol}, 1.0$ equiv.) was dissolved in dry, degassed DMF $(30 \mathrm{~mL})$ under a nitrogen atmosphere. Alkyl iodide (2.63 g, $1.35 \mathrm{~mL}, 12.8 \mathrm{mmol}, 1.05$ equiv.) and then $\mathrm{NaH}(60 \%$ dispersion in mineral oil, $632.0 \mathrm{mg}$, $15.8 \mathrm{mmol}, 1.3$ equiv.) were added to the solution at $0{ }^{\circ} \mathrm{C}$ and the reaction mixture was stirred at $0{ }^{\circ} \mathrm{C}$ for $2 \mathrm{~h}$. The desired product was purified by recrystallization from $\mathrm{EtOH}$ and obtained as red solid (3.99 $\mathrm{g}, 48 \%)$. An additional amount of product $(0.70 \mathrm{~g}, 8 \%)$ could be recovered from the recrystallization solution and was further purified by flash column chromatography $\left(\mathrm{CHCl}_{3}\right.$ :acetone=30:1). ${ }^{1} \mathrm{H} \mathrm{NMR}\left(600 \mathrm{MHz}, \mathrm{CDCl}_{3}\right) \delta 9.15(\mathrm{~s}, 1 \mathrm{H}), 8.36(\mathrm{~d}, J=9.3 \mathrm{~Hz}, 1 \mathrm{H})$, $7.97(\mathrm{~d}, J=8.1 \mathrm{~Hz}, 1 \mathrm{H}), 7.88-7.66(\mathrm{~m}, 3 \mathrm{H}), 7.65-7.44(\mathrm{~m}, 2 \mathrm{H}), 7.33(\mathrm{~d}, J=9.3 \mathrm{~Hz}, 1 \mathrm{H})$, $7.12(\mathrm{~d}, J=7.6 \mathrm{~Hz}, 1 \mathrm{H}), 6.78(\mathrm{~s}, 1 \mathrm{H}), 4.51(\mathrm{~d}, J=12.7 \mathrm{~Hz}, 1 \mathrm{H}), 4.42-4.24(\mathrm{~m}, 1 \mathrm{H}), 3.88-3.67$ $(\mathrm{m}, 2 \mathrm{H}), 3.62-3.49(\mathrm{~m}, 1 \mathrm{H}), 3.43(\mathrm{~d}, \mathrm{~J}=12.7 \mathrm{~Hz}, 1 \mathrm{H}), 3.09-2.94(\mathrm{~m}, 1 \mathrm{H}), 2.88-2.72(\mathrm{~m}$, $1 \mathrm{H}), 2.60-2.44(\mathrm{~m}, 1 \mathrm{H}), 2.43-2.17(\mathrm{~m}, 3 \mathrm{H}), 1.82(\mathrm{t}, J=18.6 \mathrm{~Hz}, 3 \mathrm{H}) .{ }^{13} \mathrm{C}\left\{{ }^{1} \mathrm{H}\right\} \mathrm{NMR}$ $\left(101 \mathrm{MHz}, \mathrm{CDCl}_{3}\right) \delta 180.1,178.5,171.2,141.2,135.1,133.8,133.5,133.4,133.4,132.6,132.2$, $131.1,130.5,130.0,129.6,129.4,127.7,127.5,127.0,125.7,124.2,123.5$ (t, J = 241.6 Hz), 71.8, 66.0, 63.3, 58.6, 40.2 (t, $J=24.9 \mathrm{~Hz}), 31.0,24.6(\mathrm{t}, J=26.8 \mathrm{~Hz}), 23.0 .{ }^{19} \mathrm{~F}$ NMR $(376 \mathrm{~Hz}$, $\left.\mathrm{CDCl}_{3}\right), \delta-84.6(\mathrm{~d}, J=239.6 \mathrm{~Hz}),-86.6(\mathrm{~d}, J=240.4 \mathrm{~Hz})$. ATR-FTIR (neat) 1673, 1636, 1589 , 1532, 1461, 1395, 1362, 1337, 1312, 1273, 1245, 1229,1162, 1142, 1117, 1064, 1031, 905, 878, 844, 823, 706, 685, 488, $446 \mathrm{~cm}^{-1}$. HRMS (ESI-TOF) $m / z:[\mathrm{M}+\mathrm{H}]^{+}$Calcd for $\mathrm{C}_{30} \mathrm{H}_{26} \mathrm{Cl}_{3} \mathrm{~F}_{2} \mathrm{~N}_{3} \mathrm{NiO}_{3}$ 678.0441; Found 678,0468. Anal Calcd for $\mathrm{C}_{30} \mathrm{H}_{26} \mathrm{Cl}_{3} \mathrm{~F}_{2} \mathrm{~N}_{3} \mathrm{NiO}_{3}$ : C, 53.02; H, 3.86; N, 6.18. Found: C, 53.09; H, 4.60; N, 6.26.

\section{Ni(II)-Schiff base complex of PfpGly (19)}

According to general procedure D, Ni (II) complex (9.07 g, $14.95 \mathrm{mmol}, 1.0$ equiv.) was dissolved in dry, degassed DMF $(37 \mathrm{~mL})$ under a nitrogen atmosphere. Alkyl iodide (4.08 g, $2.0 \mathrm{~mL}, 15.7 \mathrm{mmol}, 1.05$ equiv.) and then $\mathrm{NaH}(60 \%$ dispersion in mineral oil, $777.2 \mathrm{mg}$, 19.4 mmol, 1.3 equiv.) were added to the solution at $0{ }^{\circ} \mathrm{C}$ and the reaction mixture was stirred at $0{ }^{\circ} \mathrm{C}$ for $2 \mathrm{~h}$. The desired product was purified by recrystallization from EtOH and obtained as red solid (4.86 g, 44\%). An additional amount of product $(0.59 \mathrm{~g}, 5 \%)$ could be recovered 
from the recrystallization solution and was further purified by flash column chromatography $\left(\mathrm{CHCl}_{3}\right.$ :acetone=30:1). ${ }^{1} \mathrm{H} \mathrm{NMR}\left(600 \mathrm{MHz}, \mathrm{CDCl}_{3}\right) \delta 9.14(\mathrm{~s}, 1 \mathrm{H}), 8.37(\mathrm{~d}, J=9.3 \mathrm{~Hz}, 1 \mathrm{H})$, $7.93(\mathrm{~d}, J=8.2 \mathrm{~Hz}, 1 \mathrm{H}), 7.85-7.67(\mathrm{~m}, 3 \mathrm{H}), 7.57$ (d, $J=8.1 \mathrm{~Hz}, 1 \mathrm{H}), 7.54-7.48(\mathrm{~m}, 1 \mathrm{H})$, $7.33(\mathrm{~d}, J=9.3 \mathrm{~Hz}, 1 \mathrm{H}), 7.08(\mathrm{~d}, J=7.7 \mathrm{~Hz}, 1 \mathrm{H}), 6.78(\mathrm{~s}, 1 \mathrm{H}), 4.57-4.40$ (m, 2H), $3.84-3.74$ $(\mathrm{m}, 1 \mathrm{H}), 3.71-3.59(\mathrm{~m}, 1 \mathrm{H}), 3.59-3.49(\mathrm{~m}, 1 \mathrm{H}), 3.44$ (d, J=12.6 Hz, 1H), $3.02-2.91(\mathrm{~m}$, $1 \mathrm{H}), 2.86-2.60(\mathrm{~m}, 2 \mathrm{H}), 2.42-2.32(\mathrm{~m}, 1 \mathrm{H}), 2.31-2.15(\mathrm{~m}, 2 \mathrm{H}) .{ }^{13} \mathrm{C}\left\{{ }^{1} \mathrm{H}\right\} \mathrm{NMR}(101 \mathrm{MHz}$, $\left.\mathrm{CDCl}_{3}\right) \delta 180.2,177.4,172.4,141.4,135.0,133.8,133.6,133.4,133.2,133.0,132.3,131.2$, $130.9,130.0,129.8,129.6,127.5,127.1,126.7,125.8,124.3,119.9-113.7$ (m, 2C), 71.7, 64.2, 63.4, 58.6, $32.1(\mathrm{t}, J=19.5 \mathrm{~Hz}), 31.0,23.0 .{ }^{19} \mathrm{~F} \mathrm{NMR}\left(376 \mathrm{~Hz}, \mathrm{CDCl}_{3}\right) \delta-85.9,-112.3(\mathrm{dd}, J=$ 263.3, 34.3 Hz), -115.1 (dd, $J=260.9,33.0 \mathrm{~Hz}$ ). ATR-FTIR (neat) 1681, 1641, 1584, 1532 , 1461, 1397, 1337, 1318, 1246, 1193, 1166, 1117, 1091, 1060, 1016, 977, 884, 825, 724, 707, 692, 667, 598, 518, 508, 494, 477, $450 \mathrm{~cm}^{-1}$. HRMS (ESI-TOF) $\mathrm{m} / z$ : $[\mathrm{M}+\mathrm{H}]^{+}$Calcd for $\mathrm{C}_{30} \mathrm{H}_{23} \mathrm{Cl}_{3} \mathrm{~F}_{5} \mathrm{~N}_{3} \mathrm{NiO}_{3}$ 732.0159; Found 732.0229. Anal Calcd for $\mathrm{C}_{30} \mathrm{H}_{23} \mathrm{Cl}_{3} \mathrm{~F}_{5} \mathrm{~N}_{3} \mathrm{NiO}_{3}$ : C, 49.12; H, 3.16; N, 5.73. Found: C, 49.35; H, 3.56; N, 5.77.

\section{Ni(II)-Schiff base complex of TfVal (16)}

According to general procedure $\mathbf{D}$, Ni (II) complex (20.00 g, $33.2 \mathrm{mmol}, 1.0$ equiv.) was dissolved in dry, degassed DMF ( $83 \mathrm{~mL})$ under a nitrogen atmosphere. Alkyl iodide (7.82 g, $34.8 \mathrm{mmol}, 1.05$ equiv.) and then $\mathrm{NaH}$ (60\% dispersion in mineral oil, $2.67 \mathrm{~g}, 66.5 \mathrm{mmol}$, 2.0 equiv.) were added to the solution at $0{ }^{\circ} \mathrm{C}$ and the reaction mixture was stirred at $0{ }^{\circ} \mathrm{C}$ for $2 \mathrm{~h}$. The desired products were purified by flash column chromatography $\left(\mathrm{CHCl}_{3}\right.$ :acetone $\left.=30: 1\right)$ and obtained as red solids $((2 S, 3 R)$-isomer: $5.65 \mathrm{~g}, 24 \%$; $(2 S, 3 S)$ isomer: $6.50 \mathrm{~g}, 28 \%$ ).

(2S,3S)-isomer 16a: ${ }^{1} \mathrm{H}$ NMR (600 MHz, $\left.\mathrm{CDCl}_{3}\right) \delta 8.99$ (d, $\left.J=2.1 \mathrm{~Hz}, 1 \mathrm{H}\right), 8.17(\mathrm{~d}, J=9.3$ $\mathrm{Hz}, 1 \mathrm{H}), 7.65(\mathrm{dd}, J=8.2,2.1 \mathrm{~Hz}, 1 \mathrm{H}), 7.62-7.54(\mathrm{~m}, 2 \mathrm{H}), 7.52(\mathrm{t}, J=7.4,1.6 \mathrm{~Hz}, 1 \mathrm{H}), 7.36$ $-7.27(\mathrm{~m}, 2 \mathrm{H}), 7.10(\mathrm{dd}, J=9.3,2.6 \mathrm{~Hz}, 1 \mathrm{H}), 6.89(\mathrm{~d}, J=7.5 \mathrm{~Hz}, 1 \mathrm{H}), 6.56(\mathrm{~d}, J=2.6 \mathrm{~Hz}$, $1 \mathrm{H}), 4.30(\mathrm{~d}, J=12.6 \mathrm{~Hz}, 1 \mathrm{H}), 3.98(\mathrm{~d}, J=3.6 \mathrm{~Hz}, 1 \mathrm{H}), 3.61-3.48(\mathrm{~m}, 1 \mathrm{H}), 3.46-3.34$ (m, $1 \mathrm{H}), 3.31(\mathrm{dd}, J=10.6,6.7 \mathrm{~Hz}, 1 \mathrm{H}), 3.17$ (d, $J=12.6 \mathrm{~Hz}, 1 \mathrm{H}), 2.84-2.72$ (m, 1H), 2.59 (dq, $J=13.4,8.7 \mathrm{~Hz}, 1 \mathrm{H}), 2.34-2.20(\mathrm{~m}, 1 \mathrm{H}), 2.16-1.96(\mathrm{~m}, 2 \mathrm{H}), 1.01(\mathrm{~d}, J=7.3 \mathrm{~Hz}, 3 \mathrm{H})$. ${ }^{13} \mathrm{C}\left\{{ }^{1} \mathrm{H}\right\} \mathrm{NMR}\left(101 \mathrm{MHz}, \mathrm{CDCl}_{3}\right) \delta 180.0,175.7,171.8,141.4,135.2,133.9,133.5,133.4$, 133.0, 133.0, 132.4, 131.1, 130.6, 129.9, 129.8, 129.6, 127.6, 127.3 (q, $J=282.3 \mathrm{~Hz}$ ), 127.1, 127.0, 125.7, 124.0, 71.9, 69.4, 63.6, 58.6, 42.7 (q, $J=26.7 \mathrm{~Hz}), 30.9,22.5,11.8 .{ }^{19} \mathrm{~F} \mathrm{NMR}$ $\left(376 \mathrm{~Hz}, \mathrm{CDCl}_{3}\right) \delta-64.9(\mathrm{~d}, J=9.1 \mathrm{~Hz})$. ATR-FTIR (neat) 1677, 1638, 1579, 1571, 1527, 1458, 
$1395,1335,1315,1265,1240,1180,1163,1134,1111,1089,1080,1054,1031,1014,946$, 877, 829, 724, 710, 691, 681, 665, 597, 550, 544, 506, 452, 441, $425 \mathrm{~cm}^{-1}$. HRMS (ESI-TOF) $m / z$ : $[\mathrm{M}+\mathrm{Na}]^{+}$Calcd for $\mathrm{C}_{30} \mathrm{H}_{25} \mathrm{Cl}_{3} \mathrm{~F}_{3} \mathrm{~N}_{3} \mathrm{NiO}_{3}$ 718.0165; Found 718.0231. Anal Calcd for $\mathrm{C}_{30} \mathrm{H}_{25} \mathrm{Cl}_{3} \mathrm{~F}_{3} \mathrm{~N}_{3} \mathrm{NiO}_{3}$ : C, 51.65; H, 3.61; N, 6.02. Found: C, 54.67; H, 3.91; N, 6.59.

(2S,3R)-isomer 16b: ${ }^{1} \mathrm{H} \mathrm{NMR}\left(600 \mathrm{MHz}, \mathrm{CDCl}_{3}\right) \delta 8.99(\mathrm{~d}, J=2.1 \mathrm{~Hz}, 1 \mathrm{H}), 8.17$ (d, $J=9.3$ $\mathrm{Hz}, 1 \mathrm{H}), 7.65(\mathrm{dd}, J=8.2,2.1 \mathrm{~Hz}, 1 \mathrm{H}), 7.62-7.54(\mathrm{~m}, 2 \mathrm{H}), 7.52(\mathrm{t}, J=7.4,1.6 \mathrm{~Hz}, 1 \mathrm{H}), 7.36$ $-7.27(\mathrm{~m}, 2 \mathrm{H}), 7.10(\mathrm{dd}, J=9.3,2.6 \mathrm{~Hz}, 1 \mathrm{H}), 6.89(\mathrm{~d}, J=7.5 \mathrm{~Hz}, 1 \mathrm{H}), 6.56(\mathrm{~d}, J=2.6 \mathrm{~Hz}$, $1 \mathrm{H}), 4.30(\mathrm{~d}, J=12.6 \mathrm{~Hz}, 1 \mathrm{H}), 3.98(\mathrm{~d}, J=3.6 \mathrm{~Hz}, 1 \mathrm{H}), 3.61-3.48(\mathrm{~m}, 1 \mathrm{H}), 3.46-3.34(\mathrm{~m}$, $1 \mathrm{H}), 3.31(\mathrm{dd}, J=10.6,6.7 \mathrm{~Hz}, 1 \mathrm{H}), 3.17$ (d, $J=12.6 \mathrm{~Hz}, 1 \mathrm{H}), 2.84-2.72$ (m, 1H), 2.59 (dq, $J=13.4,8.0 \mathrm{~Hz}, 1 \mathrm{H}), 2.34-2.20(\mathrm{~m}, 1 \mathrm{H}), 2.16-1.96(\mathrm{~m}, 2 \mathrm{H}), 1.01(\mathrm{~d}, J=8.0 \mathrm{~Hz}, 3 \mathrm{H})$. ${ }^{13} \mathrm{C}\left\{{ }^{1} \mathrm{H}\right\} \mathrm{NMR}\left(101 \mathrm{MHz}, \mathrm{CDCl}_{3}\right) \delta 180.0,175.2,172.3,141.1,135.1,133.8,133.6,133.5$, $133.1,132.7,132.5,131.2,130.8,129.90,129.80,129.5,127.4,127.3,127.1,126.0,125.4(q$, $J=280.9 \mathrm{~Hz}) 123.9,71.6,68.5,63.6,58.4,43.0(\mathrm{q}, J=28.1 \mathrm{~Hz}), 31.0,23.3,10.1 .{ }^{19} \mathrm{~F}$ NMR $\left(376 \mathrm{~Hz}, \mathrm{CDCl}_{3}\right) \delta-69.5(\mathrm{~d}, J=9.2 \mathrm{~Hz}$ ). ATR-FTIR (neat) 1694, 1629, 1589, 1536, 1460, 1395, 1351, 1333, 1315, 1276, 1246, 1176, 1164, 1133, 1104, 1059, 1021, 890, 829, 811, 740, 714, $703,685,668,556,543,509,451,446,425 \mathrm{~cm}^{-1}$. HRMS (ESI-TOF) $\mathrm{m} / z$ : $[\mathrm{M}+\mathrm{Na}]^{+}$Calcd for $\mathrm{C}_{30} \mathrm{H}_{25} \mathrm{Cl}_{3} \mathrm{~F}_{3} \mathrm{~N}_{3} \mathrm{NiO}_{3}$ 718.0165; Found 718.0230. Anal Calcd for $\mathrm{C}_{30} \mathrm{H}_{25} \mathrm{Cl}_{3} \mathrm{~F}_{3} \mathrm{~N}_{3} \mathrm{NiO}_{3}$ : C, 51.65; H, 3.61; N, 6.02. Found: C, 49.61; H, 4.01; N, 5.77.

\section{Ni(II)-Schiff base complex of TfIle (17)}

According to general procedure $\mathbf{D}$, Ni (II) complex (20.00 g, $33.2 \mathrm{mmol}, 1.0$ equiv.) was dissolved in dry, degassed DMF $(200 \mathrm{~mL})$ under a nitrogen atmosphere. Alkyl iodide $(8.31 \mathrm{~g}$, 34.9 mmol, 1.05 equiv.) and then $\mathrm{NaH}(60 \%$ dispersion in mineral oil, $2.67 \mathrm{~g}, 66.5 \mathrm{mmol}$, 2.0 equiv.) were added to the solution at $0{ }^{\circ} \mathrm{C}$ and the reaction mixture was stirred at $0{ }^{\circ} \mathrm{C}$ for $2 \mathrm{~h}$. The desired products were purified by flash column chromatography $\left(\mathrm{CHCl}_{3}\right.$ :acetone $\left.=30: 1\right)$ and obtained as red solids $((2 \mathrm{~S}, 3 \mathrm{R})$-isomer: $2.63 \mathrm{~g}, 11 \%$ (brsm 14\%); $(2 S, 3 S)$-isomer: $4.31 \mathrm{~g}, 18 \%$ (brsm 23\%)). An additional amount of starting material could be recovered (4.10 g, $26.4 \mathrm{mmol}, 21 \%)$.

(2S,3R)-isomer 17b: ${ }^{1} \mathrm{H}$ NMR $\left(600 \mathrm{MHz}, \mathrm{CDCl}_{3}\right) \delta 8.93(\mathrm{~s}, 1 \mathrm{H}), 8.17(\mathrm{~d}, J=9.1 \mathrm{~Hz}, 1 \mathrm{H}), 7.68$ $(\mathrm{d}, J=8.1 \mathrm{~Hz}, 1 \mathrm{H}), 7.64-7.45$ (m, 3H), $7.40-7.28$ (m, 2H), $7.13(\mathrm{~d}, J=9.3 \mathrm{~Hz}, 1 \mathrm{H}), 6.86(\mathrm{~d}$, $J=7.6 \mathrm{~Hz}, 1 \mathrm{H}), 6.60(\mathrm{~s}, 1 \mathrm{H}), 4.50-4.36(\mathrm{~m}, 1 \mathrm{H}), 4.32$ (d, $J=12.5 \mathrm{~Hz}, 1 \mathrm{H}), 3.88-3.77$ (m, $1 \mathrm{H}), 3.60-3.47(\mathrm{~m}, 1 \mathrm{H}), 3.46-3.26(\mathrm{~m}, 2 \mathrm{H}), 3.22(\mathrm{~d}, J=12.6 \mathrm{~Hz}, 1 \mathrm{H}), 2.82-2.71(\mathrm{~m}, 1 \mathrm{H})$, 
$2.71-2.59(\mathrm{~m}, 1 \mathrm{H}), 2.42-2.18(\mathrm{~m}, 2 \mathrm{H}), 2.15-2.00(\mathrm{~m}, 2 \mathrm{H}), 0.85(\mathrm{~d}, J=6.9 \mathrm{~Hz}, 3 \mathrm{H}) .{ }^{13} \mathrm{C}\left\{{ }^{1} \mathrm{H}\right\}$ NMR (101 MHz, $\left.\mathrm{CDCl}_{3}\right) \delta 180.0,176.8,171.9,141.0,134.9,133.8,133.7,133.5,133.0,132.9$, 132.6, 131.2, 130.5, 130.1 (q, $J=160.1 \mathrm{~Hz}$ ), 129.8, 129.6, 129.5, 127.7, 127.2, 127.2, 126.0, 124.0, 74.1, 71.6, 63.1, 58.3, 35.9 (q, $J=28.1 \mathrm{~Hz}), 33.8,31.0,23.2,17.0 .{ }^{19} \mathrm{~F}$ NMR $(376 \mathrm{~Hz}$, $\left.\mathrm{CDCl}_{3}\right) \delta-63.1(\mathrm{t}, J=11.2 \mathrm{~Hz}$ ). ATR-FTIR (neat) 1673, 1650, 1581, 1528, 1461, 1396, 1336, $1311,1277,1244,1166,1138,1117,1075,1053,1031,971,884,832,823,722,707,685,664$, 588, 541, 497, 472, 438, $416 \mathrm{~cm}^{-1}$. HRMS (ESI-TOF) $m / z:[\mathrm{M}+\mathrm{H}]^{+}$Calcd for $\mathrm{C}_{31} \mathrm{H}_{27} \mathrm{Cl}_{3} \mathrm{~F}_{3} \mathrm{~N}_{3} \mathrm{NiO}_{3}$ 710.0504; Found 710.0584. Anal Calcd for $\mathrm{C}_{31} \mathrm{H}_{27} \mathrm{Cl}_{3} \mathrm{~F}_{3} \mathrm{~N}_{3} \mathrm{NiO}_{3}$ : C, 52.32; H, 3.82; N, 5.91. Found: C, 52.36; H, 3.97; N, 5.94.

(2S,3S)-isomer 17a: ${ }^{1} \mathrm{H} \mathrm{NMR}\left(600 \mathrm{MHz}, \mathrm{CDCl}_{3}\right) \delta 8.97(\mathrm{~s}, 1 \mathrm{H}), 8.16(\mathrm{~d}, J=9.3 \mathrm{~Hz}, 1 \mathrm{H}), 7.70$ $-7.65(\mathrm{~m}, 1 \mathrm{H}), 7.63-7.52(\mathrm{~m}, 2 \mathrm{H}), 7.49$ (t, $J=7.5 \mathrm{~Hz}, 1 \mathrm{H}), 7.34(\mathrm{~d}, J=8.1 \mathrm{~Hz}, 1 \mathrm{H}), 7.30$ (d, $J=7.4 \mathrm{~Hz}, 1 \mathrm{H}), 7.12(\mathrm{dd}, J=9.3,2.6 \mathrm{~Hz}, 1 \mathrm{H}), 6.88(\mathrm{~d}, J=7.6 \mathrm{~Hz}, 1 \mathrm{H}), 6.58(\mathrm{dd}, J=9.3,2.6$ Hz, 1H), 4.33 (d, $J=12.6 \mathrm{~Hz}, 1 \mathrm{H}), 3.99$ (d, $J=3.4 \mathrm{~Hz}, 1 \mathrm{H}), 3.64-3.50$ (m, 1H), $3.44-3.29$ (m, 2H), $3.22(\mathrm{~d}, J=12.5 \mathrm{~Hz}, 1 \mathrm{H}), 2.83-2.69(\mathrm{~m}, 1 \mathrm{H}), 2.69-2.53(\mathrm{~m}, 1 \mathrm{H}), 2.25-2.13(\mathrm{~m}$, $4 \mathrm{H}), 2.13-1.96(\mathrm{~m}, 3 \mathrm{H}), 1.96-1.85(\mathrm{~m}, 1 \mathrm{H}) .{ }^{13} \mathrm{C}\left\{{ }^{1} \mathrm{H}\right\} \mathrm{NMR}\left(101 \mathrm{MHz}, \mathrm{CDCl}_{3}\right) \delta 180.0$, 177.0, 171.8, 140.9, 135.1, 133.8, 133.6, 133.5, 132.8, 132.8, 132.5, 131.2, 130.5, 129.8, 129.6, 129.5, 127.5, 127.3, 126.9, 125.9, 124.8 (q, $J=157.0 \mathrm{~Hz}), 123.9,73.1,71.6,63.6,58.3,36.8$ $(\mathrm{q}, J=28.1 \mathrm{~Hz}), 32.2,31.0,23.1,16.1 .{ }^{19} \mathrm{~F} \mathrm{NMR}\left(376 \mathrm{~Hz}, \mathrm{CDCl}_{3}\right) \delta-64.4(\mathrm{t}, J=11.1 \mathrm{~Hz})$. ATR-FTIR (neat) 1669, 1636, 1584, 1532, 1461, 1395, 1351, 1335, 1316, 1276, 1247, 1166, 1137, 1062, 1033, 919, 882, 826, 748, 722, 708, 689, 663, 600, 548, 540, 499, 478, $441 \mathrm{~cm}^{-1}$. HRMS (ESI-TOF) $m / z$ : $[\mathrm{M}+\mathrm{H}]^{+}$Calcd for $\mathrm{C}_{31} \mathrm{H}_{27} \mathrm{Cl}_{3} \mathrm{~F}_{3} \mathrm{~N}_{3} \mathrm{NiO}_{3}$ 710.0504; Found 710.0593. Anal Calcd for $\mathrm{C}_{31} \mathrm{H}_{27} \mathrm{Cl}_{3} \mathrm{~F}_{3} \mathrm{~N}_{3} \mathrm{NiO}_{3}$ : C, 52.32; H, 3.82; N, 5.91. Found: C, 50.35; H, 4.10; N, 5.62 .

(S)-2-((((9H-fluoren-9-yl)methoxy)carbonyl)amino)-4-fluorobutanoic acid (Monofluoroethylglycine, MfeGly) (2)

According to general procedure E, alkylated Ni (II) complex (16.00 g, 24.7 mmol, 1.0 equiv.) was dissolved in dimethoxyethane $(82 \mathrm{~mL})$ and $3 \mathrm{M}$ aqueous $\mathrm{HCl}$ solution $(41.1 \mathrm{~mL}$, $123.55 \mathrm{mmol}, 5.0$ equiv.) was added. After the recovery of the ligand (11.65 g, 90\%), $\mathrm{MeCN}$ $(49 \mathrm{~mL})$ and EDTA $\mathrm{Na}_{2}(9.20 \mathrm{~g}, 24.7 \mathrm{mmol}, 1.0$ equiv. $)$ were added to the filtrate and the reaction mixture was stirred at $23{ }^{\circ} \mathrm{C}$ for $2 \mathrm{~h}$. The $\mathrm{pH}$ of the solution was adjusted to 7 and subsequently $\mathrm{Na}_{2} \mathrm{CO}_{3}(5.24 \mathrm{~g}, 49.4 \mathrm{mmol}, 2.0$ equiv.) was added to the mixture. FmocOSu (8.34 g, 24.7 mmol, 1.0 equiv.) was dissolved in acetone $(99 \mathrm{~mL})$ and added dropwise to the 
reaction solution. The desired product was obtained after recrystallization from hexane/EtOAc as colorless solid (7.42 g, 87\%, 96\% purity determined by analytical HPLC). ${ }^{1} \mathrm{H}$ NMR (600 $\left.\mathrm{MHz}, \mathrm{CD}_{3} \mathrm{OD}\right) \delta 7.76(\mathrm{~d}, J=7.6 \mathrm{~Hz}, 2 \mathrm{H}), 7.64(\mathrm{t}, J=7.6 \mathrm{~Hz}, 2 \mathrm{H}), 7.36$ (t, $\left.J=7.5 \mathrm{~Hz}, 3 \mathrm{H}\right)$, $7.28(\mathrm{t}, J=7.5 \mathrm{~Hz}, 2 \mathrm{H}), 4.58-4.40(\mathrm{~m}, 2 \mathrm{H}), 4.39-4.25(\mathrm{~m}, 3 \mathrm{H}), 4.19(\mathrm{t}, J=7.0 \mathrm{~Hz}, 1 \mathrm{H}), 2.27$ (dddt, $J=19.6,14.1,9.2,5.0 \mathrm{~Hz}, 1 \mathrm{H}), 1.98$ (dddt, $J=29.3,14.1,9.6,4.7 \mathrm{~Hz}, 1 \mathrm{H}) .{ }^{13} \mathrm{C}\left\{{ }^{1} \mathrm{H}\right\}$ NMR (101 MHz, $\left.\mathrm{CDCl}_{3}\right) \delta$ 174.0, 157.4, 143.9 (d, $\left.J=21.2 \mathrm{~Hz}, 2 \mathrm{C}\right), 141.3$ (2C), 127.5 (2C), 126.8 (d, $J=4.2 \mathrm{~Hz}, 2 \mathrm{C}), 124.9$ (d, $J=2.9 \mathrm{~Hz}, 2 \mathrm{C}), 119.6$ (2C), 80.1 (d, $J=165.1 \mathrm{~Hz}), 66.7$, 50.5, 47.1, $32.1(\mathrm{~d}, J=20.5 \mathrm{~Hz}) .{ }^{19} \mathrm{~F}$ NMR $\left(376 \mathrm{~Hz}, \mathrm{CDCl}_{3}\right) \delta-222.5--222.8(\mathrm{~m})$. ATR-FTIR (neat) 3335, 2961, 1711, 1683, 1532, 1449, 1430, 1315, 1254, 1174, 1105, 1084, 1044, 1029, 977, 938, 894, 798, 783, 759, 736, 621, 584, 548, 485, $425 \mathrm{~cm}^{-1}$. HRMS (ESI-TOF) $\mathrm{m} / \mathrm{z}$ : $[\mathrm{M}+\mathrm{Na}]^{+}$Calcd for $\mathrm{C}_{19} \mathrm{H}_{18} \mathrm{FNO}_{4}$ 366.1118; Found 366.1091. Anal Calcd for $\mathrm{C}_{19} \mathrm{H}_{18} \mathrm{FNO}_{4}$ : $\mathrm{C}$, 66.46; H, 5.28; N, 4.08. Found: C, 66.68; H, 5.28; N, 4.11. $[\alpha]_{\mathrm{D}}^{25}=-0.5\left(\right.$ lit.:-0.6 $\left.{ }^{17}\right)(\mathrm{c}=0.98$, $\mathrm{MeOH})$.

\section{(S)-2-((((9H-fluoren-9-yl)methoxy)carbonyl)amino)-4,4-difluorobutanoic acid} (Difluoroethylglycine, DfeGly) (3)

According to general procedure E, alkylated Ni (II) complex (16.00 g, 24.0 mmol, 1.0 equiv.) was dissolved in dimethoxyethane $(80 \mathrm{~mL})$ and $3 \mathrm{M}$ aqueous $\mathrm{HCl}$ solution $(40.0 \mathrm{~mL}$, $120.2 \mathrm{mmol}, 5.0$ equiv.) was added. After the recovery of the ligand (10.95 g, 87\%), MeCN $(48 \mathrm{~mL})$ and EDTA $\mathrm{Na}_{2}(8.95 \mathrm{~g}, 24.0 \mathrm{mmol}, 1.0$ equiv. $)$ were added to the filtrate and the reaction mixture was stirred at $23{ }^{\circ} \mathrm{C}$ for $2 \mathrm{~h}$. The $\mathrm{pH}$ of the solution was adjusted to 7 and subsequently $\mathrm{Na}_{2} \mathrm{CO}_{3}(5.10 \mathrm{~g}, 48.1 \mathrm{mmol}, 2.0$ equiv.) was added to the mixture. FmocOSu $(8.11 \mathrm{~g}, 24.0 \mathrm{mmol}, 1.0$ equiv.) was dissolved in acetone $(96 \mathrm{~mL})$ and added dropwise to the reaction solution. The desired product was obtained after recrystallization from hexane/EtOAc as colorless solid (7.55 g, 87\%, 98\% purity determined by analytical HPLC). ${ }^{1} \mathrm{H}$ NMR (600 $\left.\mathrm{MHz}, \mathrm{CD}_{3} \mathrm{OD}\right) \delta 7.75(\mathrm{~d}, J=7.6 \mathrm{~Hz}, 2 \mathrm{H}), 7.63(\mathrm{t}, J=6.7 \mathrm{~Hz}, 2 \mathrm{H}), 7.35$ (t, $\left.J=7.5 \mathrm{~Hz}, 2 \mathrm{H}\right)$, $7.27(\mathrm{t}, J=7.4 \mathrm{~Hz}, 2 \mathrm{H}), 5.92(\mathrm{tt}, J=56.4,4.7 \mathrm{~Hz}, 1 \mathrm{H}), 4.42-4.29(\mathrm{~m}, 3 \mathrm{H}), 4.19(\mathrm{t}, J=7.0 \mathrm{~Hz}$, $1 \mathrm{H}), 2.44-2.32(\mathrm{~m}, 1 \mathrm{H}), 2.27-2.14(\mathrm{~m}, 1 \mathrm{H}) .{ }^{13} \mathrm{C}\left\{{ }^{1} \mathrm{H}\right\} \mathrm{NMR}\left(101 \mathrm{MHz}, \mathrm{CDCl}_{3}\right) \delta 172.8$, 157.1, 143.9 (d, $J=18.2 \mathrm{~Hz}, 2 \mathrm{C}), 141.3$ (2C), 127.5 (2C), 126.8 (2C), 124.9 (2C), 119.6 (2C), $115.7(\mathrm{t}, J=238.1 \mathrm{~Hz}), 66.7,49.1(\mathrm{t}, J=6.3 \mathrm{~Hz}), 47.0,35.7(\mathrm{t}, J=22.8 \mathrm{~Hz}) .{ }^{19} \mathrm{~F}$ NMR $(376 \mathrm{~Hz}$, $\left.\mathrm{CDCl}_{3}\right) \delta-117.5--119.0$ (m). ATR-FTIR (neat) 3311, 2970, 1705, 1683, 1527, 1449, 1403, 1289, 1261, 1243, 1177, 1117, 1103, 1083, 1067, 1049, 1028, 908, 780, 758, 738, 645, 620, 588, 544, 509, 481, $426 \mathrm{~cm}^{-1}$. HRMS (ESI-TOF) $\mathrm{m} / z$ : $[\mathrm{M}+\mathrm{Na}]^{+}$Calcd for $\mathrm{C}_{19} \mathrm{H}_{17} \mathrm{~F}_{2} \mathrm{NO}_{4}$ 
384.1024; Found 384.1026. Anal Calcd for $\mathrm{C}_{19} \mathrm{H}_{17} \mathrm{~F}_{2} \mathrm{NO}_{4}$ : C, 63.16; H, 4.74; N, 3.88. Found: C, 63.54; H, 4.87; N, 4.06. $[\alpha]_{\mathrm{D}}^{25}=-21.8(\mathrm{c}=1.01, \mathrm{MeOH})$.

\section{(S)-2-((((9H-fluoren-9-yl)methoxy)carbonyl)amino)-4,4-difluoropentanoic acid}

\section{(Difluoropropylglyine, DfpGly) (6)}

According to general procedure $\mathbf{E}$, alkylated $\mathrm{Ni}$ (II) complex (3.81 g, $5.6 \mathrm{mmol}, 1.0$ equiv.) was dissolved in dimethoxyethane $(20 \mathrm{~mL})$ and $3 \mathrm{M}$ aqueous $\mathrm{HCl}$ solution $(9.4 \mathrm{~mL}$, $28.05 \mathrm{mmol}, 5.0$ equiv.) was added. After the recovery of the ligand $(2.50 \mathrm{~g}, 85 \%), \mathrm{MeCN}$ $(11 \mathrm{~mL})$ and EDTA $\mathrm{Na}_{2}(2.09 \mathrm{~g}, 5.6 \mathrm{mmol}, 1.0$ equiv.) were added to the filtrate and the reaction mixture was stirred at $23{ }^{\circ} \mathrm{C}$ for $2 \mathrm{~h}$. The $\mathrm{pH}$ of the solution was adjusted to 7 and subsequently $\mathrm{Na}_{2} \mathrm{CO}_{3}(1.19 \mathrm{~g}, 11.2 \mathrm{mmol}, 2.0$ equiv.) was added to the mixture. FmocOSu $(1.89 \mathrm{~g}, 5.6 \mathrm{mmol}, 1.0$ equiv.) was dissolved in acetone $(22 \mathrm{~mL})$ and added dropwise to the reaction solution. The desired product was obtained after recrystallization from hexane/EtOAc as colorless solid (1.56 g, 74\%, 98\% purity determined by analytical HPLC). ${ }^{1} \mathrm{H}$ NMR (600 $\left.\mathrm{MHz}, \mathrm{CD}_{3} \mathrm{OD}\right) \delta 7.75(\mathrm{~d}, J=7.6 \mathrm{~Hz}, 2 \mathrm{H}), 7.63(\mathrm{t}, J=6.6 \mathrm{~Hz}, 2 \mathrm{H}), 7.35$ (t, $\left.J=7.5 \mathrm{~Hz}, 2 \mathrm{H}\right)$, $7.27(\mathrm{t}, J=7.5 \mathrm{~Hz}, 2 \mathrm{H}), 4.46-4.26(\mathrm{~m}, 3 \mathrm{H}), 4.19(\mathrm{t}, J=7.0 \mathrm{~Hz}, 1 \mathrm{H}), 2.48(\mathrm{dtd}, J=16.3,14.1$, $3.5 \mathrm{~Hz}, 1 \mathrm{H}), 2.28(\mathrm{dtd}, J=16.3,15.0,9.8 \mathrm{~Hz}, 1 \mathrm{H}), 1.59(\mathrm{t}, J=18.0 \mathrm{~Hz}, 3 \mathrm{H}) .{ }^{13} \mathrm{C}\left\{{ }^{1} \mathrm{H}\right\} \mathrm{NMR}$ $\left(101 \mathrm{MHz}, \mathrm{CDCl}_{3}\right) \delta 173.2,157.0,143.9$ (d, $\left.J=16.6 \mathrm{~Hz}, 2 \mathrm{C}\right), 141.2$ (2C), 127.4 (2C), 126.8 (2C), 124.9 (2C), 123.1 (t, $J=237.4 \mathrm{~Hz}), 119.6(2 \mathrm{C}), 66.7,49.5$ (t, $J=5.0 \mathrm{~Hz}), 47.0,38.6$ (t, $J$ $=26.3 \mathrm{~Hz}), 22.4(\mathrm{t}, J=27.2 \mathrm{~Hz}) .{ }^{19} \mathrm{~F} \mathrm{NMR}\left(376 \mathrm{~Hz}, \mathrm{CDCl}_{3}\right) \delta-89.0(\mathrm{dtq}, J=243.4,34.2,18.0$ Hz), -90.7 (dtq, $J=243.4,34.2,18.0 \mathrm{~Hz}$ ). ATR-FTIR (neat) 3314, 2968, 1696, 1545, 1525, 1450, 1421, 1396, 1310, 1277, 1252, 1229, 1170, 1119, 1080, 1057, 1039, 981, 946, 936, 915, $903,859,807,757,736,646,622,587,552,523,428 \mathrm{~cm}^{-1}$. HRMS (ESI-TOF) $\mathrm{m} / z:[\mathrm{M}+\mathrm{Na}]^{+}$ Calcd for $\mathrm{C}_{20} \mathrm{H}_{19} \mathrm{~F}_{2} \mathrm{NO}_{4}$ 398.1180; Found 398.1200. Anal Calcd for $\mathrm{C}_{20} \mathrm{H}_{19} \mathrm{~F}_{2} \mathrm{NO}_{4}$ : C, 64.00; $\mathrm{H}$, 5.10; N, 3.73. Found: C, 61.97; H, 5.68; N, 4.38. $[\alpha]_{\mathrm{D}}{ }^{25}=-18.8(\mathrm{c}=0.97, \mathrm{MeOH})$.

(S)-2-((((9H-fluoren-9-yl)methoxy) carbonyl)amino)-4,4,5,5,5-pentafluoropentanoic acid (Pentafluoropropylglycine, PfpGly) (7)

According to general procedure E, alkylated Ni (II) complex (4.62 g, 6.3 mmol, 1.0 equiv.) was dissolved in dimethoxyethane $(22 \mathrm{~mL})$ and $3 \mathrm{M}$ aqueous $\mathrm{HCl}$ solution $(10.5 \mathrm{~mL}$, $31.5 \mathrm{mmol}, 5.0$ equiv.) was added. After the recovery of the ligand (2.84 g, 86\%), MeCN $(14 \mathrm{~mL})$ and EDTA $\mathrm{Na}_{2}(2.35 \mathrm{~g}, 6.3 \mathrm{mmol}, 1.0$ equiv.) were added to the filtrate and the 
reaction mixture was stirred at $23{ }^{\circ} \mathrm{C}$ for $2 \mathrm{~h}$. The $\mathrm{pH}$ of the solution was adjusted to 7 and subsequently $\mathrm{Na}_{2} \mathrm{CO}_{3}(1.34 \mathrm{~g}, 12.6 \mathrm{mmol}, 2.0$ equiv.) was added to the mixture. FmocOSu ( $2.13 \mathrm{~g}, 6.30 \mathrm{mmol}, 1.0$ equiv.) was dissolved in acetone $(25 \mathrm{~mL})$ and added dropwise to the reaction solution. The desired product was obtained after recrystallization from hexane/EtOAc as colorless solid (2.06 g, 76\%, 94\% purity determined by analytical HPLC). ${ }^{1} \mathrm{H}$ NMR (600 $\left.\mathrm{MHz}, \mathrm{CD}_{3} \mathrm{OD}\right) \delta 7.76(\mathrm{~d}, J=7.6 \mathrm{~Hz}, 2 \mathrm{H}), 7.64(\mathrm{~d}, J=5.4 \mathrm{~Hz}, 1 \mathrm{H}), 7.36(\mathrm{t}, J=7.5 \mathrm{~Hz}, 2 \mathrm{H})$, $7.27(\mathrm{t}, J=7.3 \mathrm{~Hz}, 2 \mathrm{H}), 4.54(\mathrm{dd}, J=9.8,3.3 \mathrm{~Hz}, 1 \mathrm{H}), 4.32(\mathrm{~d}, J=7.2 \mathrm{~Hz}, 2 \mathrm{H}), 4.20$ (t, $J=7.2$ $\mathrm{Hz}, 1 \mathrm{H}), 2.86-2.70(\mathrm{~m}, 1 \mathrm{H}), 2.69-2.52(\mathrm{~m}, 1 \mathrm{H}) .{ }^{13} \mathrm{C}\left\{{ }^{1} \mathrm{H}\right\} \mathrm{NMR}\left(101 \mathrm{MHz}, \mathrm{CDCl}_{3}\right) \delta 171.9$, 156.9, 143.9 (d, $J=4.8 \mathrm{~Hz}, 2 \mathrm{C})$ ), 141.2 (2C), 127.5 (2C), 126.8 (d, $J=2.6 \mathrm{~Hz}, 2 \mathrm{C}), 125.9$ 112.7 (m, 2C), $124.9(2 \mathrm{C}), 119.6(2 \mathrm{C}), 66.9,48.2,47.0,31.4(\mathrm{t}, J=20.7 \mathrm{~Hz}) .{ }^{19} \mathrm{~F} \mathrm{NMR}(376 \mathrm{~Hz}$, $\left.\mathrm{CDCl}_{3}\right) \delta-87.3,-118.4$ (ddd, $\left.J=267.3,28.4,9.6 \mathrm{~Hz}\right),-119.5(\mathrm{ddd}, J=267.3,26.1,8.5 \mathrm{~Hz})$. ATR-FTIR (neat) 3339, 2940, 1720, 1696, 1529, 1447, 1429, 1346, 1295, 1274, 1234, 1214, 1202, 1187, 1119, 1104, 1055, 1025, 923, 914, 759, 739, 624, 587, 538, 471, $427 \mathrm{~cm}^{-1}$. HRMS (ESI-TOF) $m / z$ : $[\mathrm{M}+\mathrm{Na}]^{+}$Calcd for $\mathrm{C}_{20} \mathrm{H}_{16} \mathrm{~F}_{5} \mathrm{NO}_{4}$ 452.0897; Found 452.0931. Anal Calcd for $\mathrm{C}_{20} \mathrm{H}_{16} \mathrm{~F}_{5} \mathrm{NO}_{4}$ : C, 55.95; H, 3.76; N, 3.26. Found: C, 56.03; H, 3.50; N, 3.43. $[\alpha]_{\mathrm{D}}^{25}=-20.4$ $(\mathrm{c}=1.00, \mathrm{MeOH})$.

(2S, 3S)-2-((((9H-fluoren-9-yl)methoxy) carbonyl)amino)-4,4,4-trifluoro-3-methylbutanoic acid ((2S,3S)-Trifluorovaline, $(2 S, 3 S)-T f V a l)(4 a)$

According to general procedure E, alkylated Ni (II) complex (6.33 g, 9.1 mmol, 1.0 equiv.) was dissolved in dimethoxyethane $(32 \mathrm{~mL})$ and $3 \mathrm{M}$ aqueous $\mathrm{HCl}$ solution $(15.1 \mathrm{~mL}$, $45.35 \mathrm{mmol}, 5.0$ equiv.) was added. After the recovery of the ligand (4.39 g, 92\%), $\mathrm{MeCN}$ $(19 \mathrm{~mL})$ and EDTA $\mathrm{Na}_{2}(3.38 \mathrm{~g}, 9.1 \mathrm{mmol}, 1.0$ equiv.) were added to the filtrate and the reaction mixture was stirred at $23{ }^{\circ} \mathrm{C}$ for $2 \mathrm{~h}$. The $\mathrm{pH}$ of the solution was adjusted to 7 and subsequently $\mathrm{Na}_{2} \mathrm{CO}_{3}(1.92 \mathrm{~g}, 18.1 \mathrm{mmol}, 2.0$ equiv.) was added to the mixture. FmocOSu (3.06 g, $9.1 \mathrm{mmol}, 1.0$ equiv.) was dissolved in acetone $(36 \mathrm{~mL})$ and added dropwise to the reaction solution. The desired product was obtained after recrystallization from hexane/EtOAc as colorless solid (2.98 g, 84\%, 91\% purity determined by analytical HPLC). ${ }^{1} \mathrm{H}$ NMR (600 $\left.\mathrm{MHz}, \mathrm{CD}_{3} \mathrm{OD}\right) \delta 7.76(\mathrm{~d}, J=7.6 \mathrm{~Hz}, 2 \mathrm{H}), 7.65(\mathrm{~d}, J=7.5 \mathrm{~Hz}, 2 \mathrm{H}), 7.36(\mathrm{t}, J=7.5 \mathrm{~Hz}, 2 \mathrm{H})$, $7.27(\mathrm{t}, J=7.5 \mathrm{~Hz}, 2 \mathrm{H}), 4.79-4.72(\mathrm{~m}, 1 \mathrm{H}), 4.33(\mathrm{qd}, J=10.6,7.2 \mathrm{~Hz}, 2 \mathrm{H}), 4.21(\mathrm{t}, J=7.2$ $\mathrm{Hz}, 1 \mathrm{H}), 3.04-2.92(\mathrm{~m}, 1 \mathrm{H}), 1.16(\mathrm{~d}, J=7.2 \mathrm{~Hz}, 3 \mathrm{H}) .{ }^{13} \mathrm{C}\left\{{ }^{1} \mathrm{H}\right\} \mathrm{NMR}\left(101 \mathrm{MHz}, \mathrm{CDCl}_{3}\right) \delta$ 171.6, 157.3 (d, $J=8.6 \mathrm{~Hz}), 143.9$ (d, $J=6.0 \mathrm{~Hz}, 2 \mathrm{C}), 141.2$ (2C), 127.5 (2C), 127.2 (q, $\mathrm{J}=279.9 \mathrm{~Hz}), 126.8(\mathrm{~d}, J=3.4 \mathrm{~Hz}, 2 \mathrm{C}), 125.0(\mathrm{~d}, J=2.7 \mathrm{~Hz}, 2 \mathrm{C}), 119.6(2 \mathrm{C}), 66.9,52.6,47.0$, 
$39.3(\mathrm{q}, J=26.6 \mathrm{~Hz}), 7.3 .{ }^{19} \mathrm{~F} \mathrm{NMR}\left(376 \mathrm{~Hz}, \mathrm{CDCl}_{3}\right) \delta-72.3(\mathrm{t}, J=7.9 \mathrm{~Hz})$. ATR-FTIR (neat) 3304, 3067, 1730, 1694, 1539, 1391, 1373, 1338, 1321, 1261, 1242, 1236, 1223, 1186, 1164 , 1133, 1106, 1084 1039, 1015, 981, 882, 754, 734, 685, 671, 663, 592, 529, 508, 445, $426 \mathrm{~cm}^{-}$ ${ }^{1}$. HRMS (ESI-TOF) $m / z$ : $[\mathrm{M}+\mathrm{Na}]^{+}$Calcd for $\mathrm{C}_{20} \mathrm{H}_{18} \mathrm{~F}_{3} \mathrm{NO}_{4}$ 416.1086; Found 416.1124. Anal Calcd for $\mathrm{C}_{20} \mathrm{H}_{18} \mathrm{~F}_{3} \mathrm{NO}_{4}$ : C, 61.07; H, 4.61; N, 3.56. Found: C, 61.12; H, 4.76; N, 3.71. $[\alpha]_{\mathrm{D}}{ }^{25}=-$ $14.5(\mathrm{c}=1.07, \mathrm{MeOH})$.

(2S,3R)-2-((((9H-fluoren-9-yl)methoxy) carbonyl)amino)-4,4,4-trifluoro-3-methylbutanoic acid ((2S,3R)-Trifluorovaline, $(2 S, 3 R)$-TfVal) $(\mathbf{4 b})$

According to general procedure E, alkylated Ni (II) complex (5.43 g, 7.8 mmol, 1.0 equiv.) was dissolved in dimethoxyethane $(27 \mathrm{~mL})$ and $3 \mathrm{M}$ aqueous $\mathrm{HCl}$ solution $(13.0 \mathrm{~mL}$, 38.9 mmol, 5.0 equiv.) was added. After the recovery of the ligand (3.84 g, 94\%), MeCN $(16 \mathrm{~mL})$ and EDTA $\mathrm{Na}_{2}(2.90 \mathrm{~g}, 7.8 \mathrm{mmol}, 1.0$ equiv.) were added to the filtrate and the reaction mixture was stirred at $23{ }^{\circ} \mathrm{C}$ for $2 \mathrm{~h}$. The $\mathrm{pH}$ of the solution was adjusted to 7 and subsequently $\mathrm{Na}_{2} \mathrm{CO}_{3}(1.65 \mathrm{~g}, 15.6 \mathrm{mmol}, 2.0$ equiv.) was added to the mixture. FmocOSu (2.62 g, $7.8 \mathrm{mmol}, 1.0$ equiv.) was dissolved in acetone $(31 \mathrm{~mL})$ and added dropwise to the reaction solution. The desired product was obtained after recrystallization from hexane/EtOAc as colorless solid (2.48 g, 81\%, 97\% purity determined by analytical HPLC). ${ }^{1} \mathrm{H}$ NMR (600 $\left.\mathrm{MHz}, \mathrm{CD}_{3} \mathrm{OD}\right) \delta 7.76(\mathrm{~d}, J=7.6 \mathrm{~Hz}, 2 \mathrm{H}), 7.64(\mathrm{t}, J=6.4 \mathrm{~Hz}, 2 \mathrm{H}), 7.36$ (t, $\left.J=7.5 \mathrm{~Hz}, 2 \mathrm{H}\right)$, $7.27(\mathrm{t}, J=7.5 \mathrm{~Hz}, 2 \mathrm{H}), 4.47(\mathrm{~d}, J=5.5 \mathrm{~Hz}, 1 \mathrm{H}), 4.42-4.27(\mathrm{~m}, 2 \mathrm{H}), 4.21(\mathrm{t}, J=7.1 \mathrm{~Hz}, 1 \mathrm{H})$, $3.01-2.90(\mathrm{~m}, 1 \mathrm{H}), 1.17(\mathrm{~d}, J=7.2 \mathrm{~Hz}, 3 \mathrm{H}) .{ }^{13} \mathrm{C}\left\{{ }^{1} \mathrm{H}\right\} \mathrm{NMR}\left(101 \mathrm{MHz}, \mathrm{CDCl}_{3}\right) \delta 171.4,157.2$, $143.8(\mathrm{~d}, J=25.4 \mathrm{~Hz}, 2 \mathrm{C}), 141.3$ (2C), 127.5 (2C), 127.3 (q, J = 280.4 Hz), 126.8 (2C), 124.9 $(\mathrm{d}, J=3.1 \mathrm{~Hz}, 2 \mathrm{C}), 119.6(2 \mathrm{C}), 66.9,54.0,47.0,40.0$ (q, $J=25.7 \mathrm{~Hz}), 10.0 .{ }^{19} \mathrm{~F} \mathrm{NMR}(376 \mathrm{~Hz}$, $\left.\mathrm{CDCl}_{3}\right) \delta-70.3(\mathrm{~d}, J=9.4 \mathrm{~Hz})$. ATR-FTIR (neat) 3301, 3070, 1723, 1698, 1542, 1447, 1371, 1312, 1266, 1235, 1182, 1163, 1134, 1105, 1087, 1033, 1016, 984, 942 883, 754, 734, 702, 669, 650, 636, 599, 559, 538, 480, $427 \mathrm{~cm}^{-1}$. HRMS (ESI-TOF) $\mathrm{m} / z:[\mathrm{M}+\mathrm{Na}]^{+}$Calcd for $\mathrm{C}_{20} \mathrm{H}_{18} \mathrm{~F}_{3} \mathrm{NO}_{4}$ 416.1086; Found 416.1130. Anal Calcd for $\mathrm{C}_{20} \mathrm{H}_{18} \mathrm{~F}_{3} \mathrm{NO}_{4}$ : C, 61.07; H, 4.61; N, 3.56. Found: C, 61.05; H, 4.69; N, 3.66. $[\alpha]_{\mathrm{D}}^{25}=-6.4(\mathrm{c}=1.02, \mathrm{MeOH})$. 
(2S,3R)-2-((((9H-fluoren-9-yl)methoxy) carbonyl)amino)-5,5,5-trifluoro-3-methylpentanoic acid $\left(5^{3}-(2 S, 3 R)\right.$-Trifluoroisoleucine, $5^{3}-(2 S, 3 R)$-TfIle) (5b)

According to general procedure E, alkylated Ni (II) complex (2.53 g, $3.6 \mathrm{mmol}, 1.0$ equiv.) was dissolved in dimethoxyethane $(13 \mathrm{~mL})$ and $3 \mathrm{M}$ aqueous $\mathrm{HCl}$ solution $(5.9 \mathrm{~mL}, 17.8 \mathrm{mmol}$, 5.0 equiv.) was added. After the recovery of the ligand (1.59 g, 84\%), $\mathrm{MeCN}(7.5 \mathrm{~mL})$ and EDTA $\mathrm{Na}_{2}(1.53 \mathrm{~g}, 3.6 \mathrm{mmol}, 1.0$ equiv.) were added to the filtrate and the reaction mixture was stirred at $23{ }^{\circ} \mathrm{C}$ for $2 \mathrm{~h}$. The $\mathrm{pH}$ of the solution was adjusted to 7 and subsequently $\mathrm{Na}_{2} \mathrm{CO}_{3}$ (754.6 mg, $7.1 \mathrm{mmol}, 2.0$ equiv.) was added to the mixture. FmocOSu (1.20 g, $3.6 \mathrm{mmol}$, 1.0 equiv.) was dissolved in acetone $(14 \mathrm{~mL})$ and added dropwise to the reaction solution. The desired product was obtained after recrystallization from hexane/EtOAc as colorless solid (730.0 mg, 50\%, 99\% purity determined by analytical HPLC). ${ }^{1} \mathrm{H}$ NMR (600 MHz, $\left.\mathrm{CD}_{3} \mathrm{OD}\right) \delta$ $\delta 7.76(\mathrm{~d}, J=7.7 \mathrm{~Hz}, 2 \mathrm{H}), 7.65(\mathrm{t}, J=8.1 \mathrm{~Hz}, 2 \mathrm{H}), 7.35(\mathrm{t}, J=7.5 \mathrm{~Hz}, 2 \mathrm{H}), 7.27(\mathrm{t}, J=6.6 \mathrm{~Hz}$, $1 \mathrm{H}), 4.43-4.35(\mathrm{~m}, 2 \mathrm{H}), 4.33(\mathrm{~d}, J=4.1 \mathrm{~Hz}, 1 \mathrm{H}), 4.26-4.13(\mathrm{~m}, 1 \mathrm{H}), 2.53-2.45(\mathrm{~m}, 1 \mathrm{H})$, $2.31(\mathrm{dqd}, J=16.4,11.6,4.8 \mathrm{~Hz}, 1 \mathrm{H}), 2.04-1.87(\mathrm{~m}, 1 \mathrm{H}), 0.99(\mathrm{~d}, J=7.0 \mathrm{~Hz}, 3 \mathrm{H}) .{ }^{13} \mathrm{C}\left\{{ }^{1} \mathrm{H}\right\}$ NMR (101 MHz, $\left.\mathrm{CDCl}_{3}\right) \delta 172.6,157.7,143.9(\mathrm{~d}, J=47.7 \mathrm{~Hz}, 2 \mathrm{C}), 141.3(2 \mathrm{C}), 127.5(\mathrm{~d}, J=$ $3.4 \mathrm{~Hz}, 2 \mathrm{C}), 127.2$ (q, J = 276.9 Hz), 126.8 (d, $J=4.1 \mathrm{~Hz}, 2 \mathrm{C}), 124.9$ (d, $J=4.8 \mathrm{~Hz}, 2 \mathrm{C}), 119.6$ $(\mathrm{d}, J=5.6 \mathrm{~Hz}, 2 \mathrm{C}), 66.6,57.7,47.2,36.6$ (q, $J=27.8 \mathrm{~Hz}), 30.1,13.9 .{ }^{19} \mathrm{~F} \mathrm{NMR}\left(376 \mathrm{~Hz}, \mathrm{CDCl}_{3}\right)$ $\delta-65.2$ (t, $J=11.4 \mathrm{~Hz}$ ). ATR-FTIR (neat) 3394, 3157, 1747, 1686, 1536, 1453, 1396, 1329, 1286, 1252, 1238, 1193, 1172, 1136, 1091, 1059, 1045, 1016, 976, 934, 816, 760, 742, 732, 681, 621, 579, 550, 524, $425 \mathrm{~cm}^{-1}$. HRMS (ESI-TOF) $\mathrm{m} / z$ : $[\mathrm{M}+\mathrm{Na}]^{+}$Calcd for $\mathrm{C}_{21} \mathrm{H}_{20} \mathrm{~F}_{3} \mathrm{NO}_{4}$ 430.1242; Found 430.1243. Anal Calcd for $\mathrm{C}_{21} \mathrm{H}_{20} \mathrm{~F}_{3} \mathrm{NO}_{4}$ : $\mathrm{C}, 61.91 ; \mathrm{H}, 4.95 ; \mathrm{N}, 3.44$. Found: C, 61.95; H, 4.99; N, 3.50. $[\alpha]_{\mathrm{D}}^{25}=-4.5(\mathrm{c}=0.95, \mathrm{MeOH})$.

\section{(2S,3S)-2-((((9H-fluoren-9-yl)methoxy)carbonyl)amino)-5,5,5-trifluoro-3-methylpentanoic} acid ( $5^{3}-(2 S, 3 S)$-Trifluoroisoleucine, $5^{3}-(2 S, 3 S)$-TfIle) (5a)

According to general procedure E, alkylated Ni (II) complex (4.21 g, 5.9 mmol, 1.0 equiv.) was dissolved in dimethoxyethane $(21 \mathrm{~mL})$ and $3 \mathrm{M}$ aqueous $\mathrm{HCl}$ solution $(9.9 \mathrm{~mL}, 29.6 \mathrm{mmol}$, 5.0 equiv.) was added. After the recovery of the ligand $(2.67 \mathrm{~g}, 86 \%), \mathrm{MeCN}(12.5 \mathrm{~mL})$ and EDTA Na2 $(2.20 \mathrm{~g}, 5.92 \mathrm{mmol}, 1.0$ equiv.) were added to the filtrate and the reaction mixture was stirred at $23{ }^{\circ} \mathrm{C}$ for $2 \mathrm{~h}$. The $\mathrm{pH}$ of the solution was adjusted to 7 and subsequently $\mathrm{Na}_{2} \mathrm{CO}_{3}$ (755 mg, $7.1 \mathrm{mmol}, 2.0$ equiv.) was added to the mixture. FmocOSu (2.00 g, $5.9 \mathrm{mmol}, 1.0$ equiv.) was dissolved in acetone $(24 \mathrm{~mL})$ and added dropwise to the reaction solution. The desired product was obtained after recrystallization from hexane/EtOAc as colorless solid 
(1.60 g, 66\%, 93\% purity determined by analytical HPLC). ${ }^{1} \mathrm{H}$ NMR $\left(600 \mathrm{MHz}, \mathrm{CD}_{3} \mathrm{OD}\right) \delta$ $7.75(\mathrm{~d}, J=7.6 \mathrm{~Hz}, 2 \mathrm{H}), 7.63$ (t, $J=7.6 \mathrm{~Hz}, 2 \mathrm{H}), 7.34$ (t, $J=7.5 \mathrm{~Hz}, 2 \mathrm{H}), 7.27$ (t, $J=7.4 \mathrm{~Hz}$, 2H), $4.39-4.32(\mathrm{~m}, 2 \mathrm{H}), 4.21(\mathrm{~d}, J=4.8 \mathrm{~Hz}, 1 \mathrm{H}), 4.19$ (t, $J=6.9 \mathrm{~Hz}, 1 \mathrm{H}), 2.42-2.20$ (m, 2H), $2.16-2.01(\mathrm{~m}, 1 \mathrm{H}), 1.05(\mathrm{~d}, J=6.8 \mathrm{~Hz}, 3 \mathrm{H}) .{ }^{13} \mathrm{C}\left\{{ }^{1} \mathrm{H}\right\} \mathrm{NMR}\left(101 \mathrm{MHz}, \mathrm{CDCl}_{3}\right) \delta 172.6$, 157.4, 143.9 (d, $J=35.4 \mathrm{~Hz}, 2 \mathrm{C}), 141.3$ (2C), 127.5 (2C), 127.3 (q, J = 276.5 Hz), 126.8 (d, $J$ $=3.8 \mathrm{~Hz}, 2 \mathrm{C}), 124.9$ (d, $J=3.0 \mathrm{~Hz}, 2 \mathrm{C}), 119.6(\mathrm{~d}, J=3.4 \mathrm{~Hz}, 2 \mathrm{C}), 66.6,58.4,47.1,35.7$ (d, $J$ $=27.7 \mathrm{~Hz}), 30.4,15.5 .{ }^{19} \mathrm{~F}$ NMR $\left(376 \mathrm{~Hz}, \mathrm{CDCl}_{3}\right) \delta-65.0(\mathrm{t}, J=11.6 \mathrm{~Hz})$. ATR-FTIR (neat) 3391, 2977, 1747, 1737, 1684, 1540, 1451, 1396, 1330, 1290, 1251, 1236, 1193, 1175, 1138, $1088,1060,1045,1016,975,934,864,857,832,814,773,759,740,731,680,641,620,583$, 549, 541, $426 \mathrm{~cm}^{-1}$. HRMS (ESI-TOF) $\mathrm{m} / z$ : $[\mathrm{M}+\mathrm{Na}]^{+}$Calcd for $\mathrm{C}_{21} \mathrm{H}_{20} \mathrm{~F}_{3} \mathrm{NO}_{4}$ 430.1242; Found 430.1308. Anal Calcd for $\mathrm{C}_{21} \mathrm{H}_{20} \mathrm{~F}_{3} \mathrm{NO}_{4}$ : C, 61.91; H, 4.95; N, 3.44. Found: C, 62.02; H, 5.01; $\mathrm{N}, 3.47 .[\alpha]_{\mathrm{D}}^{25}=-6.7(\mathrm{c}=1.08, \mathrm{MeOH})$.

\section{Associated content}

Supporting information The Supporting Information is available free of charge.

(Additional experimental details and methods)

(X-ray data, checkCIFs)

\section{Conflict of interest}

The authors declare no conflict of interest.

\section{Acknowledgements}

T.H. thanks the Studienstiftung des deutschen Volkes for financial support. B.K., T.H, M.D. and S.C gratefully acknowledge financial support by the Deutsche Forschungsgemeinschaft (DFG) through the collaborative research center CRC-1349 "Fluorine-Specific Interactions", project no 387284271 . Furthermore, we would like to acknowledge the assistance of the Core Facility BioSupraMol supported by the DFG. We also would like to thank Marcel Gausmann and Prof. Dr. Mathias Christmann for providing the facility and support by the determination of specific rotations. 


\section{References}

(1) Berger, A. A.; Völler, J. S.; Budisa, N.; Koksch, B. Deciphering the Fluorine Code - The Many Hats Fluorine Wears in a Protein Environment. Accounts of Chemical Research 2017, 50 (9), 2093-2103. https://doi.org/10.1021/acs.accounts.7b00226.

(2) Buer, B. C.; Marsh, E. N. G. Fluorine: A New Element in Protein Design. Protein Science. April 2012, pp 453-462. https://doi.org/10.1002/pro.2030.

(3) Sloand, J. N.; Miller, M. A.; Medina, S. H. Fluorinated Peptide Biomaterials. Peptide Science 2021, 113 (2), e24184. https://doi.org/https://doi.org/10.1002/pep2.24184.

(4) Salwiczek, M.; Nyakatura, E. K.; Gerling, U. I. M.; Ye, S.; Koksch, B. Fluorinated Amino Acids: Compatibility with Native Protein Structures and Effects on Protein-Protein Interactions. Chemical Society Reviews 2012, 41 (6), 2135-2171. https://doi.org/10.1039/c1cs15241f.

(5) Jäckel, C.; Salwiczek, M.; Koksch, B. Fluorine in a Native Protein Environment - How the Spatial Demand and Polarity of Fluoroalkyl Groups Affect Protein Folding. Angewandte Chemie - International Edition 2006, 45 (25), 4198-4203. https://doi.org/10.1002/anie.200504387.

(6) Moschner, J.; Stulberg, V.; Fernandes, R.; Huhmann, S.; Leppkes, J.; Koksch, B. Approaches to Obtaining Fluorinated $\alpha$-Amino Acids. Chemical Reviews. American Chemical Society September 25, 2019, pp 10718-10801. https://doi.org/10.1021/acs.chemrev.9b00024.

(7) Belokon, Yu. N.; Bulychev, A. G.; Vitt, S. v; Struchkov, Yu. T.; Batsanov, A. S.; Timofeeva, T. v; Tsyryapkin, V. A.; Ryzhov, M. G.; Lysova, L. A. General Method of Diastereo- and Enantioselective Synthesis of $\beta$-Hydroxy- $\alpha$-Amino Acids by Condensation of Aldehydes and Ketones with Glycine. Journal of the American Chemical Society 1985, 107 (14), 4252-4259. https://doi.org/10.1021/ja00300a030.

(8) Zou, Y.; Han, J.; Saghyan, A. S.; Mkrtchyan, A. F.; Konno, H.; Moriwaki, H.; Izawa, K.; Soloshonok, V. A. Asymmetric Synthesis of Tailor-Made Amino Acids Using Chiral Ni(II) Complexes of Schiff Bases. An Update of the Recent Literature. Molecules. MDPI AG June 1, 2020. https://doi.org/10.3390/molecules25122739.

(9) Wang, J.; Lin, D.; Zhou, S.; Ding, X.; Soloshonok, V. A.; Liu, H. Asymmetric Synthesis of Sterically and Electronically Demanding Linear $\omega$-Trifluoromethyl Containing Amino Acids via Alkylation of Chiral Equivalents of Nucleophilic Glycine and Alanine. Journal of Organic Chemistry 2011, 76 (2), 684-687. https://doi.org/10.1021/jo102031b.

(10) Romoff, T. T.; Palmer, A. B.; Mansour, N.; Creighton, C. J.; Miwa, T.; Ejima, Y.; Moriwaki, H.; Soloshonok, V. A. Scale-up Synthesis of (R)- and (S)-N-(2-Benzoyl-4-Chlorophenyl)-1(3,4-Dichlorobenzyl)Pyrrolidine-2-Carboxamide Hydrochloride, A Versatile Reagent for the Preparation of Tailor-Made $\alpha$ - And $\beta$-Amino Acids in an Enantiomerically Pure Form.

Organic Process Research and Development 2017, 21 (5), 732-739.

https://doi.org/10.1021/acs.oprd.7b00055.

(11) Romoff, T. T.; Ignacio, B. G.; Mansour, N.; Palmer, A. B.; Creighton, C. J.; Abe, H.; Moriwaki, H.; Han, J.; Konno, H.; Soloshonok, V. A. Large-Scale Synthesis of the Glycine Schiff Base Ni(II) Complex Derived from (S)- A Nd (R)-N-(2-Benzoyl-4-Chlorophenyl)-1- 
[(3,4-Dichlorophenyl)Methyl]-2-Pyrrolidinecarboxamide. Organic Process Research and Development 2020, 24 (2), 294-300. https://doi.org/10.1021/acs.oprd.9b00399.

(12) Mei, H.; Hiramatsu, T.; Takeda, R.; Moriwaki, H.; Abe, H.; Han, J.; Soloshonok, V. A. Expedient Asymmetric Synthesis of (S)-2-Amino-4,4,4-Trifluorobutanoic Acid via Alkylation of Chiral Nucleophilic Glycine Equivalent. Organic Process Research and Development 2019, 23 (4), 629-634. https://doi.org/10.1021/acs.oprd.8b00404.

(13) Han, J.; Takeda, R.; Liu, X.; Konno, H.; Abe, H.; Hiramatsu, T.; Moriwaki, H.; Soloshonok, V. A. Preparative Method for Asymmetric Synthesis of (S)-2-Amino-4,4,4-Trifluorobutanoic Acid. Molecules 2019, 24 (24). https://doi.org/10.3390/molecules24244521.

(14) Yin, Z.; Moriwaki, H.; Abe, H.; Miwa, T.; Han, J.; Soloshonok, V. A. Large-Scale Asymmetric Synthesis of Fmoc-(S)-2-Amino-6,6,6-Trifluorohexanoic Acid. ChemistryOpen 2019, 8 (6), 701-704. https://doi.org/10.1002/open.201900131.

(15) Laue, K. W.; Kröger, S.; Wegelius, E.; Haufe, G. Stereoselective Synthesis of $\gamma$-Fluorinated $\alpha$-Amino Acids Using 2-Hydroxy-3-Pinanone as an Auxiliary. European Journal of Organic Chemistry 2000, 2000 (22), 3737-3743. https://doi.org/https://doi.org/10.1002/10990690(200011)2000:22<3737::AID-EJOC3737>3.0.CO;2-A.

(16) Wang, L.; Zha, Z.; Qu, W.; Qiao, H.; Lieberman, B. P.; Plössl, K.; Kung, H. F. Synthesis and Evaluation of $18 \mathrm{~F}$ Labeled Alanine Derivatives as Potential Tumor Imaging Agents. Nuclear Medicine and Biology 2012, 39 (7), 933-943.

https://doi.org/10.1016/J.NUCMEDBIO.2012.03.007.

(17) Leppkes, J.; Hohmann, T.; Koksch, B. Improved Enantioselective Gram Scale Synthesis Route to N-Fmoc-Protected Monofluoroethylglycine. Journal of Fluorine Chemistry 2020, 232, 109453. https://doi.org/10.1016/J.JFLUCHEM.2020.109453.

(18) Winkler, D.; Burger, K. Synthesis of Enantiomerically Pure D- and L-Armentomycin and Its Difluoro Analogues from Aspartic Acid. Synthesis 1996, 1996 (12), 1419-1421.

(19) Osipov, S. N.; Lange, T.; Tsouker, P.; Spengler, J.; Hennig, L.; Koksch, B.; Berger, S.; ElKousy, S. M.; Burger, K. Hexafluoroacetone as a Protecting and Activating Reagent: Synthesis of New Types of Fluoro-Substituted $\alpha$-Amino, $\alpha$-Hydroxy and $\alpha$-Mercapto Acids. Synthesis 2004, No. 11, 1821-1829. https://doi.org/10.1055/s-2004-829131.

(20) Yajima, T.; Nagano, H. Photoinduced Diastereoselective Addition of Perfluoroalkyl Iodides to Acrylic Acid Derivatives for the Synthesis of Fluorinated Amino Acids. Organic Letters 2007, 9 (13), 2513-2515. https://doi.org/10.1021/o10707620.

(21) Erdbrink, H.; Peuser, I.; Gerling, U. I. M.; Lentz, D.; Koksch, B.; Czekelius, C. Conjugate Hydrotrifluoromethylation of $\alpha, \beta$-Unsaturated Acyl-Oxazolidinones: Synthesis of Chiral Fluorinated Amino Acids. Organic and Biomolecular Chemistry 2012, 10 (43), 8583-8586. https://doi.org/10.1039/c2ob26810h.

(22) Chen, Q.; Qiu, X. L.; Qing, F. L. Indium-Mediated Diastereoselective Allylation of D- and LGlyceraldimines with 4-Bromo-1,1,1-Trifluoro-2-Butene: Highly Stereoselective Synthesis of 4,4,4-Trifluoroisoleucines and 4,4,4-Trifluorovaline. Journal of Organic Chemistry 2006, 71 (10), 3762-3767. https://doi.org/10.1021/jo0601157. 
(23) Pigza, J. A.; Quach, T.; Molinski, T. F. Oxazoline-Oxazinone Oxidative Rearrangement. Divergent Syntheses of (2S,3S)-4,4,4-Trifluorovaline and (2S,4S)-5,5,5-Trifluoroleucine. Journal of Organic Chemistry 2009, 74 (15), 5510-5515. https://doi.org/10.1021/jo900654y.

(24) Benhaim, C.; Bouchard, L.; Pelletier, G.; Sellstedt, J.; Kristofova, L.; Daigneault, S. Enantioselective Synthesis of $\beta$-Trifluoromethyl $\alpha$-Amino Acids. Organic Letters 2010, 12 (9), 2008-2011. https://doi.org/10.1021/ol100478d.

(25) Xing, X.; Fichera, A.; Kumar, K. A Simple and Efficient Method for the Resolution of All Four Diastereomers of 4,4,4-Trifluorovaline and 5,5,5-Trifluoroleucine. Journal of Organic Chemistry 2002, 67 (5), 1722-1725. https://doi.org/10.1021/jo011097q.

(26) Wang, Z.; Resnick, L. Practical Asymmetric Synthesis of a Novel $\gamma$-Secretase Inhibitor. Tetrahedron 2008, 64 (27), 6440-6443. https://doi.org/10.1016/J.TET.2008.04.072.

(27) Erdbrink, H.; Nyakatura, E. K.; Huhmann, S.; Gerling, U. I. M.; Lentz, D.; Koksch, B.; Czekelius, C. Synthesis of Enantiomerically Pure (2S,3S)-5,5,5-Trifluoroisoleucine and (2R,3S)-5,5,5-Trifluoro-Allo-Isoleucine. Beilstein Journal of Organic Chemistry 2013, 9, 2009-2014. https://doi.org/10.3762/bjoc.9.236.

(28) Biava, H.; Budisa, N. Obtention of Enantiomerically Pure 5,5,5-Trifluoro-1-Isoleucine and 5,5,5-Trifluoro-1-Alloisoleucine. Journal of Fluorine Chemistry 2013, 156, 372-377. https://doi.org/10.1016/J.JFLUCHEM.2013.07.021.

(29) Menczinger, B.; Nemes, A.; Szíjjártó, C.; Rábai, J. Preparation of (Perfluoroalkyl)Alkane Thiols via Zemplén Deacylation of Fluorous (Perfluoroalkyl)Alkyl Thioacetates. Journal of Fluorine Chemistry 2018, 210, 70-77. https://doi.org/10.1016/J.JFLUCHEM.2018.02.014.

(30) Hanack, M.; Ullmann, J. Facile Synthesis of Trifluoro- and Hexafluoroisopropyl Halides. The Journal of Organic Chemistry 1989, 54 (6), 1432-1435. https://doi.org/10.1021/jo00267a036.

(31) Gerling, U. I. M.; Salwiczek, M.; Cadicamo, C. D.; Erdbrink, H.; Czekelius, C.; Grage, S. L.; Wadhwani, P.; Ulrich, A. S.; Behrends, M.; Haufe, G.; Koksch, B. Fluorinated Amino Acids in Amyloid Formation: A Symphony of Size, Hydrophobicity and $\alpha$-Helix Propensity. Chemical Science 2014, 5 (2), 819-830. https://doi.org/10.1039/c3sc52932k.

(32) Chowdhary, S.; Moschner, J.; Mikolajczak, D. J.; Becker, M.; Thünemann, A. F.; Kästner, C.; Klemczak, D.; Stegemann, A. K.; Böttcher, C.; Metrangolo, P.; Netz, R. R.; Koksch, B. The Impact of Halogenated Phenylalanine Derivatives on NFGAIL Amyloid Formation. ChemBioChem 2020, 21 (24), 3544-3554. https://doi.org/10.1002/cbic.202000373.

(33) Robalo, J. R.; Vila Verde, A. Unexpected Trends in the Hydrophobicity of Fluorinated Amino Acids Reflect Competing Changes in Polarity and Conformation. Physical Chemistry Chemical Physics 2019, 21 (4), 2029-2038. https://doi.org/10.1039/c8cp07025c.

(34) Robalo, J. R.; Huhmann, S.; Koksch, B.; Vila Verde, A. The Multiple Origins of the Hydrophobicity of Fluorinated Apolar Amino Acids. Chem 2017, 3 (5), 881-897. https://doi.org/10.1016/j.chempr.2017.09.012.

(35) Chiu, H. P.; Suzuki, Y.; Gullickson, D.; Ahmad, R.; Kokona, B.; Fairman, R.; Cheng, R. P. Helix Propensity of Highly Fluorinated Amino Acids. Journal of the American Chemical Society 2006, 128 (49), 15556-15557. https://doi.org/10.1021/ja0640445. 
(36) Zhao, Y. H.; Abraham, M. H.; Zissimos, A. M. Fast Calculation of van Der Waals Volume as a Sum of Atomic and Bond Contributions and Its Application to Drug Compounds. Journal of Organic Chemistry 2003, 68 (19), 7368-7373. https://doi.org/10.1021/jo034808o. 


\section{For Table of Contents Only}

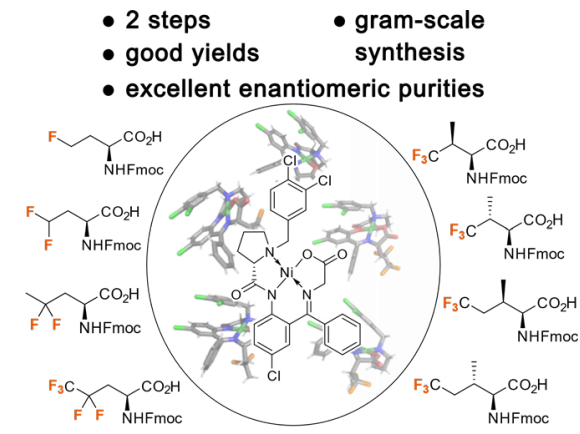

